This is a so-called personal version (author's manuscript as accepted for publishing after the review process but prior to final layout and copyediting) of the article.

Vaara, E. and Whittington, R. 2012. Strategy as Practice: Taking social practices seriously. Academy of Management Annals

Researchers are kindly asked to use the official publication in references.

\title{
Strategy-as-Practice: Taking Social Practices Seriously
}

\author{
EERO VAARA \\ Hanken School of Economics, EMLYON Business School
}

RICHARD WHITTINGTON

Said Business School, Oxford University

\begin{abstract}
This article reviews research in Strategy-as-Practice (SAP) and suggests directions for its development. The power of this perspective lies in its ability to explain how strategy-making is enabled and constrained by prevailing organizational and societal practices. Our review shows how SAP research has helped to advance social theories in strategic management, offered alternatives to performance-dominated analyzes, broadened the scope in terms of organizations studied and promoted new methodologies. In particular, it has provided important insights into the tools and methods of strategy-making (practices), how strategy work takes place (praxis), and the role and identity of the actors involved (practitioners). However, we argue that there is a need to go further in the analysis of social practices to unleash the full potential of this perspective. Hence, we outline five directions for the further development of the practice perspective: placing agency in a web of practices, recognizing the macro-institutional nature of practices, focusing attention on emergence in strategy-making, exploring how the material matters, and promoting critical analysis.
\end{abstract}

\section{Introduction}


Practice-based analyzes of organizations are becoming increasingly widespread in the management disciplines because of their special capacity to understand how organizational action is enabled and constrained by prevailing organizational and societal practices (Feldman \& Orlikowski, 2011). In particular, the last decade has seen a stream of studies focusing on activities and practices in and around strategic management, usually, but not only, under the label Strategy-as-Practice (SAP) (Golsorkhi, Rouleau, Seidl, \& Vaara, 2010; Jarzabkowski, Balogun, \& Seidl, 2007; Johnson, Melin, \& Whittington, 2003; Whittington \& Cailluet, 2008). This label carries with it a double meaning: "practice" signals both an attempt to be close to the world of practitioners and a commitment to sociological theories of practice. The key insight of these studies has been that strategy work ("strategizing") relies on organizational and other practices that significantly affect both the process and the outcome of resulting strategies. Thus, SAP research offers an alternative to the individualistic models of decision-making that still dominate the field of strategic management. While SAP research has commonalities with other approaches such as Strategy Process (Burgelman, 1983; Mintzberg \& Waters, 1985; Pettigrew, 1985) and the new Micro-Foundations approaches to strategy (Eisenhardt, Furr, \& Bingham, 2010; Foss, 2011), its focus on the ways in which actors are enabled by organizational and wider social practices in their decisions and actions provides a distinctive contribution to research on strategic management.

However, despite the achievements of this stream of research, SAP can go further in the analysis of social practices. In a nutshell, we argue that while SAP research has been very successful in enriching our knowledge of the ways in which strategizing takes place; it has not yet fully realized the potential that lies in the practice perspective, especially its recognition of how activities are embedded in broader societal or macro-institutional contexts. Here, our ideas resonate with recent calls for more epistemological and theoretical depth in SAP research (Chia \& Rasche, 2010; Ezzamel \& Willmott, 2010; McCabe, 2010; Orlikowski, 2010), as well as arguments for a linkage between institutional theory and SAP research (Smets, Morris, \& Greenwood, forthcoming; Whittington, 2010). Hence, we have two objectives in this article: (1) to provide an overview of key research in this field and (2) to suggest directions for moving forward to a fuller understanding of the central role of organizational and wider societal practices in strategy-making. Here, our concept of practices is a broad one: they are accepted ways of doing things, embodied and materially mediated, that are shared between actors and routinized over time (Reckwitz, 2002; Schatzki, Knorr-Cetina, \& von Savigny, 2001). In the following, we use "strategy-making" as an umbrella term that describes the myriad of activities that lead to the creation of organizational strategies. This includes strategizing in the sense of more or less deliberate strategy formulation, the organizing work involved in the implementation of strategies, and all the other activities that lead to the emergence of organizational strategies, conscious or not.

This article is organized as follows. We start by introducing the practice perspective in social theory, 
establishing key themes that already inform SAP research and which could motivate further research. We continue with an overview of SAP to date. We point out how SAP research has been able to bring new theoretical resources to strategic management, how it has gone beyond the strategy discipline's usual focus on economic performance per se, how it has broadened the scope of organizational types in strategy research, and how it has mobilized a variety of qualitative methods that have so far been little utilized in research on strategic management. We then focus on research findings related to practices (tools, norms, and procedures of strategy work), praxis (activity involved in strategymaking), and practitioners (actors involved in strategy-making) (Jarzabkowski et al., 2007; Whittington, 2006). We proceed to outline five directions for further progress in SAP. We first argue that it is important to go further in analyzing how agency is constituted in a web of social practices. We then propose more attention toward broader societal practices, rather than just organizational practices. We next point to the continuing potential in analyzing strategic emergence as well as deliberate planning. We contend too that, in addition to human social action, there is still plenty to explore regarding the role of material artifacts, technology, and the body in strategy-making. Finally, we explicitly encourage critical analyzes within SAP. In the last section of this article, we discuss the linkages between this approach and other perspectives in strategy research—such as Strategy Process and Micro-Foundations - and institutional approaches from within organization theory. In conclusion, we argue that practice-based approaches are in a special position to advance our understanding of strategy processes in ways that acknowledge the need for both theoretically-grounded critical reflection and practical relevance.

\section{Theories of Practice}

The origins of the practice perspective can be traced to Wittgenstein (1951) or Heidegger (1962), but the past few decades have seen a proliferation of theories of practice- to the extent that we can speak about a "practice turn" in the social sciences generally (Reckwitz, 2002; Rouse, 2007; Schatzki et al., 2001). This turn includes seminal and diverse contributions by philosophers (Foucault, 1980), sociologists (de Certeau, 1984; Giddens, 1984), anthropologists (Bourdieu, 1990), ethnomethodologists (Garfinkel, 1967), activity theorists (Engeström, Miettinen, \& Punamäki, 1999; Vygotsky, 1978), discourse scholars (Fairclough, 2003), and many more. In short, "practice” implies more than simply practical; it links strategy research to deep traditions of theoretical and empirical work in other disciplines. We highlight here how this practice turn defines itself in opposition to methodological individualism and emphasizes instead the embedded nature of human agency, the importance of macro-social institutions, emergence as well as design, the role of materiality, and the critical examination of the otherwise taken-for-granted.

Unlike many economical and psychological approaches to strategy, practice theorists distance themselves from methodological individualism, the reductionist tendency to explain behavior wholly 
in terms of the actions of discrete individuals or groups of individuals (Gross, 2009; Schatzki et al., 2001). Practice theory pays close attention to human activity, often termed "praxis" (Reckwitz, 2002). However, in practice theory, individual behavior is always embedded within a web of social practices: praxis relies on practices. The practice perspective thus confronts one of the central issues in social studies: how social structures and human agency link together in the explanation of action. For Foucault (1977), social practices in general, and discursive practices in particular, were the means through which the knowledge and power fundamental to action originally develop. To Bourdieu (1990), the notion of practice was the way to explain how the objective world and the subjective actor come together in social action. Giddens (1984), in linking social structure and human agency through structuration theory, insists on the primacy of social practices, ordered through time and space. Thus, in one way or another, the human actor is never a discrete individual detached from context, but rather a social being whose possibilities are defined by the practices in which he or she is immersed.

For practice theorists, then, practices are the substructure beneath the busy surface of events. Practice theorists particularly emphasize how these underlying practices can have significant but hidden effects. Thus, for example, discourse theorists draw attention to how actors are constituted by the everyday discursive practices they use: people are people in part because of the way they talk (Fairclough, 2003; Foucault, 1977). Similarly, the material resources of human activity, for example, technologies of communication or calculation, carry within them certain implicit practices whose constraints and affordances must be constantly negotiated according to immediate purposes (Orlikowski, 2007). The ubiquity of discourse or material technologies points to the importance of "macro-institutional" contexts in practice theory. Practices stretch across time and space to form the larger “fields” (Bourdieu, 1990), “systems” (Giddens, 1984), and “apparatuses” (Foucault, 1977) in which social action takes place and on which it relies. However, these practice fields imply no necessary determination. The contradictory and negotiable nature of practices can enable deliberate change (Giddens, 1984). Moreover, practices are always subject to incremental processes of adjustment that, in the urgency of action, are typically hardly conscious (Bourdieu, 1990). There is therefore an emergent as well as deliberate quality to social worlds. However, it remains the task of the practice theorist to uncover the taken-for-granted practices that shape social life, applying a critical lens in order to expose the unacknowledged. The same applies to social scientists themselves. Practice theorists emphasize the importance of reflexivity, that is, the need to critically examine the practices of one's own research. Thus, Foucault (1994) promoted critical analysis of bodies of knowledge and Bourdieu (1990) underscored the importance of the "sociology of sociology".

Practice theories are increasingly influential in research on management (Tengblad, 2012), management learning (Gherardi, 2009), accounting (Ahrens \& Chapman, 2006), organizations (Miettinen, Samra-Fredericks, \& Yanow, 2009), marketing (Korkman, Storbacka, \& Harald, 2010), 
and technology (Orlikowski, 2007). In this respect, SAP is part of a general trend and can learn from parallel work (Whittington, 2011). However, practice approaches are diverse. Feldman and Orlikowski (2011) distinguish three types of practice approach: empirical, theoretical, and philosophical. The empirical approach studies practices as crucial parts of the everyday activity of organizing, in both its routine and improvised forms. For SAP, this empirical approach may simply imply a micro-focus on instances of "strategizing", without substantial reliance on practice theory (Johnson et al., 2003). The theoretical approach explicitly draws from theories of practice; the focus of analysis here is on practice effects and how practices are produced, reinforced, and changed. This practice theoretical approach is thus more capable of making the link between micro-activity and macro-institutions that we shall be arguing for. The philosophical approach then involves ontological commitment to the primacy of social practices, recognized as shaping activity across time and space-a perspective that can also be used in critical analysis (Knights \& Morgan, 1991). Our point of departure is to recognize the potential value for SAP of all kinds of empirical analysis, but we argue that unleashing the full power of the practice perspective requires drawing deeper on its theoretical insights and taking its ontological commitment much more seriously.

\section{Overview of SAP Research and its Findings}

While the theoretical roots of SAP research lie in theories of practice, its substantive origins can be traced to closely-observed studies of strategy in various organizational contexts. Thus, SAP research partly draws on the Process approach to strategy-making (Bower, 1982; Burgelman, 1983; Mintzberg \& Waters, 1985), as well as other-related approaches concerning, for example, decision-making (Eisenhardt \& Bourgeois, 1988), planning (Langley, 1989), sensemaking (Gioia \& Chittipeddi, 1991), and middle-manager strategizing (Floyd \& Wooldridge, 2000). SAP research started to build a distinctive identity in the early 2000s following some earlier influential publications, both theoretical (Hendry, 2000; Knights \& Morgan, 1991; Whittington, 1996) and empirical (Jarzabkowski \& Wilson, 2002; Oakes, Townley, \& Cooper, 1998). Thereafter, we have seen a growing stream of empirical studies appearing either as individual journal articles, as parts of special issues (Jarzabkowski et al., 2007; Johnson et al., 2003; Rouleau, Allard-Poesi, \& Warnier, 2007; Whittington \& Cailluet, 2008) or as books (Golsorkhi et al., 2010; Heracleous \& Jacobs, 2011; Jarzabkowski, 2005). The predominance of conceptual articles observed by Jarzabkowski and Spee (2009) in an earlier review has been superseded.

Our review covers empirical studies orientated toward SAP and published in leading journals since 2003. ${ }^{1}$ We shall start with a general overview of some characteristic features of SAP research that distinguish it from traditional strategy research. We continue with a more detailed discussion of key articles organized according to their empirical focus on practices, praxis, or practitioners, a framework used widely in this field (Hardy, Palmer, \& Phillips, 2000; Jarzabkowski et al., 2007; Jarzabkowski \& 
Spee, 2009; Whittington, 2006). Practices refer to the various tools, norms, and procedures of strategy work, from analytical frameworks such as Porter's Five Forces to strategic planning routines such as strategy workshops. Praxis refers to the activity involved in strategy-making, for example, in strategic planning processes or meetings. Practitioners are all those involved in, or seeking to influence, strategy-making.

\section{Distinctive Features of SAP Research}

SAP enriches traditional strategy research with four distinctive features, evident from Tables 1-3. First, SAP research primarily draws on sociological theories of practice rather than economic theories. The most frequent citations in the Strategic Management Journal have been to economists such as Penrose, Porter, and Williamson (Ramos-Rodríguez \& Ruíz-Navarro, 2004). SAP research certainly links with some theoretical traditions that are well-established in strategic management, such as the Weickian sensemaking tradition (Balogun \& Johnson, 2005; Rouleau, 2005) or the dynamic capabilities perspective (Regnér, 2003; Salvato, 2003). However, as featured in Tables 1- 3, SAP also brings into strategic management research social theorists such as Abbott, Bourdieu, de Certeau, Foucault, Garfinkel, Giddens, Goffman, Habermas, Latour, and others. Here, lies the prospect of a much wider engagement by the strategic management discipline with the social sciences as a whole, taking it well beyond economics.

Second, SAP broadens the scope of what strategy research explains. Whereas "performance" has been the most important keyword in the strategic management literature in the period 1980 - 2005 (Furrer, Thomas, \& Goussevskaia, 2008), none of the studies in our review explain economic performance per se, at least directly. SAP research concerns itself with a range of outcomes, such as the political consequences of particular strategizing episodes, or the effects of strategy tools, or the involvement of particular types of practitioner. As we shall explore further, where performance does come up in the SAP literature, it often means more than just economic performance. Sometimes performance refers to how managers "perform" their roles, in Goffman's (1959) sense; sometimes it refers to "performativity", how strategy as a social practice somehow produces that which it purports simply to describe or explain (MacKenzie, 2006). Thus, SAP adds to conventional research in strategic management by extending the range of outcomes, particularly by broadening the understanding of performance.

Third, this broader explanatory remit has helped to widen the types of organizations studied. While research on strategic management typically focuses on how top managers shape the economic performance of privately-owned firms (Nag, Hambrick, \& Chen, 2007; Ronda-Pupo \& GuerrasMartin, 2011), many SAP studies have examined not-for-profit organizations, including orchestras, universities, city administrations, and public hospitals. In this sense, SAP has significantly extended 
the sectoral scope of strategic management research, taking it beyond the profit-seeking firm. Moreover, in entering these not-for-profit sectors, SAP research has had to address institutional contexts, not just narrowly-defined economic environments.

Fourth, SAP has achieved a substantial methodological shift. The strategic management discipline has traditionally preferred statistical studies, with ever increasing sample sizes (Ketchen, Boyd, \& Bergh, 2008; Phelan, Ferreira, \& Salvador, 2002). In the period 1980-2006, just 7.9\% of empirical articles in the Strategic Management Journal were purely qualitative in methodology (Molina-Azorin, 2009). SAP is the methodological mirror-image. Some studies have made use of statistics from surveys or archival sources (Gomez \& Bouty, 2011; Hodgkinson, Whittington, Johnson, \& Schwarz, 2006), but the third column in our tables shows a strong orientation toward various qualitative methods, often in single organizations. These studies have often been based on interviews, typically at many organizational levels (Mantere, 2005; Regnér, 2003). However, SAP researchers have also made remarkable efforts to get even closer to their subjects. Such methods have included participant observation (Samra-Fredericks, 2010), action research (Heracleous \& Jacobs, 2008), photography (Molloy \& Whittington, 2005), video-ethnography (Liu \& Maitlis, forthcoming), research subject diaries (Balogun \& Johnson, 2005), and work shadowing (Jarzabkowski \& Seidl, 2008). Various kinds of discursive approaches have also gained ground in recent years, closely analyzing strategy talk and texts (Clarke, Kwon, \& Wodak, 2011; Vaara, Kleymann, \& Seristo“; 2004). Intimate detail has often been achieved by tight focus on micro "episodes" of strategizing, for example, a single meeting or even a few sentences of conversation (Hendry \& Seidl, 2003; Samra-Fredericks, 2003). Some researchers are now combining such micro-analysis with a processual sensitivity to longer-run evolution by following sequences of episodes over time (Aggerholm, Asmuß, \& Thomsen, forthcoming; Denis, Dompierre, Langley, \& Rouleau, 2011; Spee \& Jarzabkowski, 2011).

\section{Practices: Enabling and Constraining Effects}

We now turn to analyses of practices. SAP scholars have addressed a wide range of practices, for example, strategic planning itself, various kinds of analytical practices, socio-material practices and, increasingly, the discursive practices of strategy. Of course, practices, praxis, and practitioners are closely interlinked, so we choose to feature here specifically those studies that place practices in the empirical foreground (Table 1). Our discussion will illustrate how, in praxis, these practices often enable actors as well as constrain them.

Strategic planning has taken a central place in SAP research, in sharp contrast to the strategic management mainstream (Furrer et al., 2008; Whittington \& Cailluet, 2008). As Ocasio and Joseph's (2008) study of General Electric indicates, Mintzberg's (1994) alleged “fall” of strategic planning in contemporary organizations is much exaggerated. Close examination of General Electric's history 
since the 1950s shows strategic planning to be a dynamically evolving practice rather than one in decline. Moreover, SAP research reveals how the practice of strategic planning can enable more complex and flexible praxis than in traditional accounts. Jarzabkowski (2003) highlights how strategic planning acts as a mediator of organizational contradictions: for instance, the very collaborative activity that strategic planning demands can help resolve the strategic challenges (e.g. lack of organizational cohesion) that it is intended to address. Hendry, Kiel, and Nicholson (2010) have shown that so-called "procedural" strategic planning, with its formal budgets and planning processes, can be used deliberately by senior managers in order to block strategic change, rather than to promote it. Nonetheless, strategic planning can also be a source of flexibility, not just rigidity. Thus, Giraudeau (2008) examines how iterative strategic planning stimulates creative elaboration with each successive iteration accommodating new understandings.

Growing attention to analytical practices challenges conventional thinking too, particularly with regard to their practical value in use. For instance, Jarratt and Stiles (2010) have identified three ways of using strategic tools: routinized behavior adopted by those who view their future as predictable; imposed engagement that over-rides the organization's collective structures; and reflective interaction between the strategist and organizational processes, culture and relationships. In this more reflective mode, strategists frequently adapt standard analytical techniques to their immediate needs. To this extent, contrary to some critics of strategic tool use (Hill \& Westbrook, 1997), there is no absolutely correct way of using tools: adaptation of standard techniques is not abuse, but assists in strategic creativity (Jarratt \& Stiles, 2010). Indeed, the attraction of simple techniques as SWOT or the Five Forces may lie not so much in their analytical power, as in their power to stimulate and communicate new insights visually, especially when represented graphically on PowerPoints or flipcharts (Eppler \& Platts, 2009). In this spirit, Moisander and Stenfors (2009) have argued that the conventional tools designed for rational problem-solving may be ill-matched to the epistemic culture of contemporary organizations, which requires tools that support collective knowledge production and learning. Furthermore, analysis itself is bound up in complex social processes. Cabantous, Gond, and JohnsonCramer (2010) show how rational decision-making techniques do not stand above the social, but require the patient and careful mobilization of practitioners, theory, and material artifacts. Once installed, rational techniques can themselves be performative, changing the basis on which organizations understand themselves and their objectives (Cabantous et al., 2010).

This appreciation of the social nature of strategy has also led SAP scholars to examine socio-material practices such as strategy meetings, workshops, and awaydays (Hodgkinson et al., 2006; Jarzabkowski \& Seidl, 2008). Thus, Jarzabkowski and Seidl (2008) show how meeting practices such as turn-taking, scheduling, issue bracketing, and voting can influence strategic discussions. For example, voting is typically used in meetings in order to kill strategic initiatives, not to rally support 
(Jarzabkowski \& Seidl, 2008). Johnson, Prashantham, Floyd, and Bourque (2010) take an anthropological lens to focus on the ritualistic aspects of strategy workshops. They show how workshops employ strategy techniques as a kind of "liturgy", with consultant facilitators performing quasi-priestly roles designed to take participants outside their earthly concerns. Others have examined the role of material artifacts in strategy. For example, Kaplan (2011) has shown the central role PowerPoint presentations in strategy meetings, with clumsy "decks" of slides liable to derail strategic initiatives. In an action research study, Heracleous and Jacobs (2008) examine how representational artifacts in the form of Lego bricks can promote new strategic understanding and consensus in senior management teams.

SAP scholars are also focusing attention on the crucial role of various discursive practices in constructing and legitimating strategy, often from a critical perspective. In an early study, Vaara et al. (2004) examined the legitimation of alliance strategies in and through discursive practices such as problematization, rationalization, objectification, reframing, and naturalization. They found, for example, that the discursive naturalization of strategies as "no choice" works as a particularly powerful practice for confirming emerging trends. More recently, strategic plans themselves have been examined in detail. For example, Vaara, Sorsa, and Pälli (2010) have analyzed how a city's strategic plan enrolled discursive practices such as self-authorization, special terminology, discursive innovation, forced consensus, and deonticity (i.e. obligation) in order to legitimate a move from the city's traditional Nordic welfare regime. Similarly, Kornberger and Clegg (2011) have highlighted the performative effects of the discursive practices surrounding the creation of a strategic plan for the city of Sydney. The language of Sydney's plan recast the city as an economic entity, prioritizing some interests while marginalizing others (Kornberger \& Clegg, 2011). Ezzamel and Willmott (2008) have in turn examined how accounting practices gained strategic significance in and through discourse, with major performative implications for the organization's strategy. Finally, in a similar spirit, Whittle and Mueller (2010) have highlighted the role of management accounting systems and the related discursive practices in the construction and legitimation of strategic ideas.

In summary, SAP studies have shown strategic practices as complex, flexible, and polyvalent. These practices go beyond simple rational strategy analysis, involving the social and the material as well. They do not impose rigid constraints, but instead enable iteration and adaptation. Further, strategy practices do more than just help decision-making: they serve to include and exclude, legitimate and delegitimate, and even, potentially, to change the very concept of the organization itself. In these various senses, SAP studies have therefore extended mainstream strategies research by bringing to light practices that have largely passed unnoticed, and discovering in them effects that previously were hardly imagined. 
Praxis: Understanding the Activity of Strategy-Making

We now turn to studies which highlight praxis, typically within focused episodes or sequences of episodes of strategy-making. One of the strengths of the practice approach generally has been to uncover the activity "inside" the process (Brown \& Duguid, 2001), in other words to delve deeper into what is actually going on. This was indeed the original motivation of the early "microstrategizing” focus of what became the SAP perspective (Johnson et al., 2003). However, SAP scholars are increasingly examining praxis not simply to document activity in itself but also to illuminate the performed nature of practices: praxis and practices are mutually constitutive. Thus, while this section focuses on studies in which activity features strongly (Table 2), it will also bring out the interdependence of practices and praxis. The outcomes of small instances of praxis are found to be sometimes unexpectedly significant: not just a strategic decision or non-decision, but also the legitimation or delegitimation of particular actors, choices, or practices.

Praxis studies are bringing an empirical directness to key themes in the strategic management literature. With regard to the resource-based view, for example, Ambrosini, Bowman, and BurtonTaylor (2007) avoid the inferential identification of differentiating resources common in mainstream research by closely observing the actual work of staff in two differently performing mortgage sales organizations: apparent details, such as how employees speak with customers and how they are physically arranged, not only matter in themselves but are highly interdependent. Similarly, Salvato (2003) uses interviews and observation to identify directly the daily activities that underlie the dynamic capabilities of two successful mid-sized companies. He found that these companies achieve dynamism by the artful recombination of stable "core micro-strategies" (e.g. consistently working with external designers), avoiding thereby disruptive change to the fundamental organizational fabric: dynamism requires a certain conservatism. Likewise, Regnér (2003) illuminates the otherwise rather broad concept of emergent strategy (Mintzberg \& Waters, 1985) by participant observation of strategy-making activities, revealing how strategies often inductively emerge from activities in the organizational periphery, by contrast to the deductive planning of the corporate center. In short, by attending closely to praxis, these SAP studies highlight the potential significance of micro-level details for concepts—-such as resources, capabilities, and emergence-that are often described empirically at a much higher level.

Another theme to which praxis studies have brought a closer focus is strategic sensemaking, where again the mainstream tradition has typically been high level (Gioia \& Chittipeddi, 1991). Balogun and Johnson (2005) draw on managers' own diaries to show how the everyday informal interactions between middle managers - the gossiping and the rumor-mongering - shaped the sensemaking around a strategic change in a manner beyond top management control. Somewhat similarly, Stensaker and Falkenberg (2007) descended down the organization to understand how the individual 
interpretations of employees and middle managers affected the implementation of a strategic change: the common experience of "unresolved sensemaking" tended to lead to organizational paralysis. These close studies of sensemaking from below reveal a greater degree of managerial haplessness than in some higher-level accounts. However, SAP studies addressing the praxis of "framing"-the deliberate manipulation of sense-allow more managerial influence over events. For instance, Sillince and Mueller (2007) describe the deliberate activities of middle managers to frame and reframe responsibility for a strategic initiative, according to its evolving prospects for success: in this way, middle managers changed the understanding and the nature of the strategy over time. Kaplan (2008) indeed casts strategy as the outcome of successive "framing contests", in which the micro-political interactions of managerial rivals in meetings and over slide decks are decisive for selected strategies.

This precarious but influential nature of strategic sensemaking and framing supports the growing concern for text and talk in SAP. For example, Samra-Fredericks (2003) has focused on the "lived experience" of managers and examined the rhetorical skills that strategists use in the moment: a few aptly-chosen words can swing a strategic conversation. Maitlis and Lawrence (2003) show how different groups within a struggling orchestra adopted the discourse of strategy as a political resource in order to support their interests and deflect criticisms from themselves. The endemic ambiguity in text and talk heightens the potential significance of skilled performance in praxis. Aggerholm et al.'s (forthcoming) examination of the evolution of a strategy text shows how the unwise smoothing over of ambiguities in the authoring stage may lead to confused and conflicting interpretations at later stages. However, ambiguity can be exploited more positively. Sillince, Jarzabkowski, and Shaw (2011) examine how, at a business school, different rhetorical practices (for example, impressionmanagement) in meetings, awaydays, and presentations were used deliberately to construct forms of ambiguity that actually allowed strategic action. Similarly, Denis et al. (2011) show that organizations can minimize conflict in the short run by employing various practices of strategic ambiguity (for example, equivocal language or inflation of objectives) that put off hard choices into the future. Spee and Jarzabkowski (2011) in turn report from their close observation of the unfolding of a strategic planning document that written texts can be used to discipline the flow and content of managerial talk, at the same time as enhancing the agency of their producers. What we take from these various studies of text and talk in action is that dis-cursive practices are typically loaded with contingency and that, in the praxis of the moment, a great deal depends on the skilled performance of the practitioner.

\section{Practitioners: Roles and Identities of Actors}

Although many of the studies above provide insights into the work of the practitioners, specific studies have also focused on the role and identity of the practitioners (Table 3). From a practice perspective, practitioners are never simple individuals: they are social beings, whose socio-political and rhetorical skills, and even national culture and gender, all make a difference to how they work 
and what they can achieve (Rouleau, 2005; Samra-Fredericks, 2005).

While mainstream strategy research has concentrated on top managers (Nag et al., 2007), SAP has extended the focus in at least two directions. First, SAP scholars are beginning to recover various kinds of strategy specialists for the research agenda. Thus, in line with evidence for the survival of strategic planning, Angwin, Paroutis, and Mitson (2009) and Whittington, Basak-Yakis, and Cailluet (2011) have documented the continued influential role of strategic planners in large organizations. What emerges from these studies is that strategic planners are far from top-down formulators and controllers of strategy, but typically precarious facilitators requiring high political and negotiating skills: strategy analysis is a small part of their job. In more detailed case studies, Paroutis and Pettigrew (2007) show corporate-level strategic planners as constantly engaged in organizing, training, and supporting business unit teams working on their own strategies. Many of these strategic planners come from a consulting background, and some research is emerging on consultants as strategy specialists. Again, strategy consultants turn out to be far more than the suppliers of analysis. At least in the family business context, consultants may play the role of "Simmelian strangers", familiar but not too close, and able to act as "social craftspersons" in the complex negotiations of strategy work (Nordqvist, 2012; Nordqvist \& Melin, 2008). Given the controversial role of strategy consultants (O’Shea \& Madigan, 1997), there is clearly scope for more research here.

The second direction in which SAP has extended the focus is its interest in the roles of middle managers in strategy. This research demonstrates the potentially crucial role of middle managers as creators, interpreters, and communicators of strategy in their organizations (Mantere, 2005, 2008; Rouleau, 2005). In this concern for middle management, SAP follows some research in the Process tradition (Floyd \& Wooldridge, 2000), but typically, it gets closer to the actors and their predicaments. For example, Rouleau (2005) has highlighted the ways in which middle managers act both as interpreters and sellers of strategy at the micro-level of customer interaction. Suominen and Mantere (2010) have in turn demonstrated how middle managers' involvement in strategy is not necessarily only "instrumental": on the one hand, they may engage with their organization's strategy "intimately", that is as something they come to identify with personally and passionately; on the other hand, they may treat it "playfully", regarding their organization's strategy with ironic detachment or skepticism. The quality of middle managers' engagement with strategy is not to be taken-for-granted. Rather, middle-managerial involvement relies on delicate mix of formal and informal mechanisms, with social networks and ad hoc "strategic conversations" particularly important (Hoon, 2007; Mantere, 2005). Moreover, Mantere (2005) indicates a frequently frustrated appetite for more strategy engagement among lower level employees outside management ranks.

SAP research has also revealed how the roles and identities of practitioners are constructed in and 
through discursive and other practices. Practices and subject positions-structures of rights that practitioners have-are closely linked. In fact, discursive analyzes have shown how strategy discourse provides ontological security and a sense of control for some, at the same time as marginalizing others (Samra-Fredericks, 2005). Thus, certain kinds of strategy discourse (e.g. mystification, disciplining, or technologization) can render some actors central as "strategists", leaving others excluded from strategizing (Mantere \& Vaara, 2008). This usually means reproduction of a division of labor where top managers are regarded as "strategists" and the role of others is simply to implement the strategies (Laine \& Vaara, 2007; McCabe, 2010). For instance, Laine and Vaara (2007) have illustrated how some managers mobilize strategy discourse to legitimate their power positions, while employees distance themselves from strategy by appeal to other discourses, such as that of engineering professionalism. McCabe (2010) has in turn elaborated on the various ways in which power is exercised and what it means for managerial initiative and resistance: the strategy discourse may be ambiguous enough to allow middle managers space for discretion at the margins.

In summary, SAP studies are beginning to recognize a wider range of actors in strategy than allowed for by the traditional focus on top management. As they do so, they are problematizing strategist roles and identities, underlining how strategy engagement or exclusion is achieved in diverse and often subtle ways.

\section{Review Summary}

As reviewed above, SAP research has helped to advance sociological theories in strategic management, offered alternative outcomes to economic performance, widened the empirical contexts of strategy research and promoted new methodologies. More specifically, SAP research has demonstrated the enabling and constraining aspects of strategy practices, the role of skilled performance in changing the course of events, and the social construction of strategy practitioners. While this growing body of research has significant theoretical and methodological implications, these in-depth analyzes also have practical implications for managers and other organizational actors: for example, analytical strategy tools should not be taken too literally; discursive ambiguity can be useful in strategy praxis; the status of "strategist" in organizations involves a struggle in which the weapons are opaque.

Thus, in its first decade, SAP has already significantly contributed to the strategic management discipline. Nevertheless, alongside others (Chia \& Rasche, 2010; Ezzamel \& Willmott, 2010; McCabe, 2010; Orlikowski, 2010; Tsoukas, 2010), we argue that there is more to be done to realize the full potential of SAP. This is especially the case with analyses of agency, where the practice approach allows one to go beyond methodological individualism, and with studies of practices, where an appreciation of fields or systems can link micro-activities to macro-level institutional phenomena. 
Furthermore, there is a plenty of research still to be done on strategy emergence, the role of materiality, and critical interpretations of strategy.

\section{Extending the Practice Perspective: Directions for Future Research}

In the following sections, we will focus on five key directions for further progress in SAP research: (1) founding agency in a web of practices, (2) giving more weight to the macro-institutional nature of practices, (3) exploring emergence in strategy-making, (4) recognizing the role of materiality, and (5) undertaking more critical analysis.

\section{Agency in a Web of Practices}

We argue first for broadening the analysis of agency in strategy-making. Strategic management has carried with it a strong emphasis on the ability of individual managers or management as a whole to steer organizations: managers are seen to exercise power in organizations through rational planning (Ansoff, 1965), strategic choices (Porter, 1980, 1986), or political action (Pettigrew, 1973). This premise has led to a widespread conceptualization of managers as independent actors and reproduced the view that strategy is the work of top management. In contrast, SAP provides means to situate the decisions and actions of managers and other organizational actors in context. In particular, the practice perspective allows one to go beyond the methodological individualism, i.e. a focus on individuals and their actions or behaviors without regarding the enabling and constraining effects of social practices.

Thus, although previous studies have made important advances, SAP can go even further in developing a nuanced understanding of strategic agency as taking place in a web of practices (see also Chia \& Holt, 2006; Chia \& Rasche, 2010; Tsoukas, 2010). We already know a great deal about practices that are associated strategic planning; however, there are other organizational practices that are not often recognized as "strategic", but still have an important role vis-à-vis strategy-making (Chia \& Rasche, 2010; Tsoukas, 2010). Thus, our point is to emphasize the diversity of these practices and the polyphony that they often produce in and around strategy-making. In this view, the agency exercised in and through strategy-making is more complex, precarious, and distributed than much of previous research indicates.

In this respect, one interesting avenue for future research is to elucidate the variety of discursive practices related to strategy-making. So far, most of previous studies have argued that strategy can be seen as a hegemonic discourse-or Mega Discourse (Alvesson \& Kärreman, 2000)—-that has significant power and ideological effects (Grandy \& Mills, 2004; Knights \& Morgan, 1991; Levy, Alvesson, \& Willmott, 2003). Rather than viewing strategy as a unified body of knowledge or hegemony, we maintain that it is important to focus attention on the various alternative discursive 
practices that enable and constrain organizational actors as practitioners of strategy (Vaara, 2010). For example, Seidl (2007) has suggested that strategy should be conceptualized not as a unified body but rather as fragmented into a multitude of autonomous discourses that take very specific forms in organizations. Boje (2008) has in turn argued that strategy-making deals with a variety of narratives that may co-exist in organizations. Empirical work has also started to deal with such polyphony and diversity. For instance, Mantere and Vaara (2008) distinguished three discourses that seemed to impede participation in strategy work and three discourses that promoted participation. These discourses resulted in struggles between competing views on strategy that in turn had significant disempowering or empowering implications on the agency of organizational members. Future studies could, however, go further in elucidating struggles related to alternative and competing discourses and explore their effects in specific contexts.

Future research could also examine how exactly actors learn to make use of discursive and other practices - and thus exercise their agency. Previous studies have provided important insights in terms of emphasizing the role of rhetorical (Samra-Fredericks, 2003, 2005) or storytelling skills (Boje, 2008). Future studies could elucidate how actors adopt and internalize specific practices. Drawing from Bourdieu, Gomez (2010) has, for example, argued that such a process involves the development of a particular kind of "habitus", i.e. dispositions that make individuals "become" strategists over time. This results in "capital” that some come to possess and others not, for example, depending on their experience and education. Allard-Poési (2010) in turn offers a Foucauldian analysis of such internalization which highlights the ways in which practices "seduce" practitioners to learn the tricks of the trade and to act "strategically" according to the dominant norms. Empirical studies of such processes are, however, lacking.

To gain a fuller understanding of how agency is exercised in and through strategy-making, future studies could focus more attention on actors beyond the managerial ranks. While SAP research has significantly contributed to our understanding of the role of managers and strategy professionals in strategy-making (Mantere, 2005; Whittington et al., 2011), our knowledge of the ways in which organizational actors such as professionals, sales persons, technological experts, or shopfloor workers contribute to strategy-making is still thin (Ezzamel \& Willmott, 2008; McCabe, 2010; Rouleau, 2005). Among other things, this has limited our understanding of the processes of resistance and the many forms that it may take (Ford, Ford, \& D’Amelio, 2008; Phllips, Sewell, \& Jaynes, 2008; Piderit, 2000). Laine and Vaara (2007) provide a rare study that highlights how middle managers and organizational members effectively resisted new top-down forms of strategic development by establishing alternative planning processes and distancing. Ezzamel and Willmott (2008) have shown how actors such as accountants can resist imposed strategies by prevarication tactics, withholding cooperation, and expressing resentment. Thomas, Sargent, and Hardy (forthcoming) in turn illustrate 
how top management's attempts to engage others depend on the communicative practices, form of dialogue, and power-resistance dynamics. Future studies can continue on this trajectory of research to elucidate how and why others engage or do not engage in strategy-making in specific contexts, including more or less passive resistance.

\section{The Macro-Institutional Nature of Practices}

A second direction for SAP research is to explore further the macro-institutional, or societal, nature of many strategy practices. Strategy research has long grasped the importance of locally-institutionalized practices, as embedded in organizational cultures or routines (Burgelman, 1983; Pettigrew, 1985). Drawing on such earlier work, SAP researchers too have shown deep appreciation for the influence of organizational practices on strategy praxis, typically through detailed case studies. But, while close attention to local context is important to practice theory, it can easily miss the larger picture. Practice theorists are concerned with wider "fields" (Bourdieu, 1990) or social "systems" (Giddens, 1984), which may stretch across organizations, industries, and whole societies. Practice theory warns against micro-myopia and offers instead a macroscopic lens.

Accordingly, "strategy" may be conceptualized as a field or social system for investigation in its own right. This field connects corporate elites, strategy consultants, financial institutions, state agencies, the business media, and business schools in the production and consumption of particular kinds of strategy discourse (Whittington et al., 2003). This understanding of strategy as a field in itself turns research attention to the interdependencies and influence of each of these kinds of actor. For example, Ghemawat (2002) points to how strategy consultants may create a bias toward innovative strategy practices that, over-sold and under-tested, often spread through whole economies with potentially disastrous effects. Yet, by comparison with other practices such as total quality management (David \& Strang, 2006), the influence of consultants on strategy practices remains under-investigated. Strategy innovators such as Boston Consulting Group (BCG) and Bain, or later Monitor and Mitchell Madison, have so far been absent from SAP research. Similar is true for financial institutions, accused of exerting pressure for short-term strategies (Lounsbury \& Hirsch, 2010). Finally, in the spirit of reflexivity, the role of the business schools in promoting particular kinds of practices of strategic management deserves investigation as well (Whittington et al., 2003).

Conceptualizing strategy as a field is also to render it socially and historically specific, rooted in a particular time and place. Knights and Morgan (1991) argue that the rise of the strategy field in the first place was linked to the historical emergence of managerial capitalism and the large corporation in post-war Western economies. Their claim is broad-brush but suggests several striking implications for research. First, it prompts open-minded research into the detailed historical mechanisms by which managerial capitalism generated particular strategy practices, along the lines of the revisionist 
histories of other pervasive managerial practices such as the multidivisional form (Freeland, 2001). Second, given the social, technological, and economical transformations that have taken place since the origins of strategic management, there is a need to understand how the strategy field is changing. Strategy in the twenty-first century is going to be very different from that in the twentieth. Third, as the balance of the world economy changes, it is also important to examine the nature of strategy as a field in societies where the large managerially-controlled corporation has never been dominant, for example, China, India, and Russia. What is strategy in societies where state or private ownership are the norms, and where Western-style business schools, strategy consultants, and investment banks are relative newcomers? For this kind of question, traditions of cross-national research on comparative institutions are likely to provide particular insight (Lampel \& Baum, 2010). Cross-national analyzes of strategic planning and other strategy practices are still scarce.

The macro-institutional lens thus treats strategy as a large-scale phenomenon that can be tracked over long periods of time and across different societies internationally. However, this macro-perspective needs always to be tempered by paying attention to local praxis, where practices are translated into particular organizational or sectoral contexts. A key learning from studies of practice movement from the private sector to other kinds of organizations is that such transfer typically involves struggle, improvisation, and compromise (Jarzabkowski, 2003; Kornberger \& Clegg, 2011; Oakes et al., 1998). Even while studying the macro-institutional character of strategy, therefore, SAP researchers should remain alert as to how practices are constantly subject to local adaptation and hybridization.

\section{Emergence in Strategy-Making}

A third important direction in SAP is to do more on emergence. To date, SAP research has concentrated on formal planning and strategizing activities (see, however, Regnér, 2003). As shown in our review, this research has greatly increased our understanding of strategy and strategizing. However, emergent strategies are important too (Mintzberg \& Waters, 1985) and these have received less attention in SAP research so far (Tsoukas, 2010). This neglect is surprising: the practice perspective's ability to pay close attention to what is actually happening in organizations gives SAP researchers a special sensitivity to the informal, unscripted activities through which strategies often emerge. Close studies of strategy emergence is a significant opportunity for advancing SAP research.

The starting point of such analysis is to focus attention on practices that have a "strategic" role in the sense that they form the basis of organizational success or survival-as in the case of routines or capabilities serving to create competitive advantage (see also Salvato, 2003). Through repetition, these practices form patterns of action that constitute emergent strategies in the Mintzbergian sense (Mintzberg \& Waters, 1985). Sometime these practices are seen as "strategic" by the focal actors or aligned with articulated strategies (formal or informal), but this is not always the case (Ambrosini et 
al., 2007). In fact, studies have demonstrated how emergent strategies may play a crucial role in peripheral strategizing (Regnér, 2003) and provide alternatives to the official truths (Burgelman, 1983).

Recent theoretical work provides conceptual frameworks that may be useful for this purpose (Chia \& Holt, 2006; Chia \& MacKay, 2007; Tsoukas, 2010). Chia and Holt (2006, 2009) contrast the conventional teleological view on strategy_-building” worldview — with the emergence of strategies non-deliberately through everyday practical coping-“dwelling” worldview. By doing so, they explain that strategy-making does not require intention and purposeful goal-orientation but dispositions to act in a manner congruent with past actions and experiences. In this view, strategy may be "immanent" in the every-day practices and actions. Thus, they offer a processual perspective to understand the emergence of strategies and how that links with prevailing practices. Chia and Rasche (2010) have further developed this view. They argue that while deliberate strategizing involves "episteme" (universal, context-independent truths) and "techne" (technical and instrumental rationalities), organizational action in the form of practical coping requires "phronesis" (practical wisdom) and occasionally "metis" (practical intelligence to deal with puzzling situations). Thus, to better understand emergence, future research should focus special attention on phronesis and metis.

Tsoukas (2010) in turn connects such a practice approach to sensemaking (drawing from Heidegger). In this view, a pattern of action becomes understood as "strategy" either by practitioners themselves when they encounter a difficult situation that needs explanation or by observers such as researchers. In both cases, "strategy" is a second-order label attributed retrospectively to patterns of actions and practices. In this view, the bulk of strategy-making is based on organizational actions and practices that are not made sense of or given sense to as "strategic" as they are happening in praxis; only occasionally do actors pause to think about "strategies" or engage in more deliberate strategizing. To what extent strategy-making is retrospective construction in praxis is therefore an open question to be tackled in future research.

Such analysis of organizational practices and the ways in which practitioners at times pause to strategize help to understand fundamental ontological and epistemological questions in strategymaking. In particular, it allows researchers to comprehend how some organizational practices-that have usually evolved over time-form the "real” basis for organizational success or survival. A close processual analysis can also reveal the very ways in which practices may be changed-either incrementally or precisely in and through deliberate strategizing. Furthermore, such analysis can help to better comprehend how and why some practices - and not others - come to be seen as "strategic" with all kinds of organizational implications (see also Ezzamel \& Willmott, 2008; Whittle \& Mueller, 2010). Thus, this kind of research has the potential to elucidate the dialectic of deliberate vs. emergent 
strategies; i.e. the way in which both deliberate and emergent strategies contribute to the evolution of organizations.

Given the importance of retrospective construction, an important-related question is how shared understandings of strategy develop in conditions of diversity and polyphony. This involves a closer analysis of conversations and narratives and how they at times create insights and shared understanding (Boje, 2008; Fenton \& Langley, 2011; Vaara \& Tienari, 2011). Interestingly, Robichaud, Giroux, and Taylor (2004) have used the concept of meta-conversation to point to ways in which multiple conversations may at times come together to create unity from diversity. Fenton and Langley (2011) have further called for a meta-narrative perspective that would precisely help to better understand how and why fragmented narratives and episodes of story-telling may at times form more or less coherent understandings of an organization's strategy.

\section{Material Matters}

A fourth direction for future research is to examine more closely the role of materiality in strategymaking. So far, our discussion has treated human actors as abstracted from the material world of which they are part. Practice sociologies such as Actor Network Theory (Latour, 2005) or the Technology-in-Use perspective (Orlikowski, 2007) point to another kind of important actor: nonhuman actants such as documents, technologies, and displays. As Callon and Law (1997) say, their illustrative "Andrew-the-Strategist" is a heterogeneous network made up not only of Andrew and his colleagues, but also his phones, his PC, his fax machine, and his train to London. Andrew would not be a strategist without all this material paraphernalia.

Combinations of material technologies and social practices constitute "genres" that significantly structure the activities of managers and other organizational members (Levina \& Orlikowski, 2009; Orlikowski \& Yates, 1994). In these ensembles of practices, material objects can play crucial roles. In particular, strategic plans can acquire a kind of "textual agency", that is the ability to exercise power over human actors and limit their degrees of freedom (Cooren, 2010; Hodge \& Coronado, 2006; Spee \& Jarzabkowski, 2009; Vaara et al., 2010). Once produced, they can be transported over space and time to be consumed in various ways. Thus, their organizational agency is still dependent on human social actors, in the sense that the texts must be consumed to have impact in organizations: practices need praxis. How all this happens requires more attention in future research (Fenton \& Langley, 2011).

More obvious technologies also shape strategizing activity. As we have already observed, techniques such as PowerPoint (Giraudeau, 2008; Kaplan, 2011) or management accounting systems (Whittle \& 
Mueller, 2010) may become "obligatory passage points" in strategy-making. However, there are opportunities for further SAP research on all the other material technologies that are becoming prevalent in contemporary strategy work, such as strategy jamming, virtual meetings, and electronic voting (Palmisano, 2004; Whittington et al., 2011). Among other things, these new technologies may promote inclusion in strategy formation and the transparency of strategy processes. However, technologization may also impede the possibilities for participation (Mantere \& Vaara, 2008).

At the same time, human actors too have a material presence. As Hodgkinson and Wright's (2002) case study of a strategy workshop indicates, the physical positioning of key actors in a meeting room can shape the unfolding of instances of strategy praxis. Practice-informed ethnographers such as Streeck, Goodwin, and LeBaron (2011) point to how activity is achieved through the multi-modal orchestration of discourse, bodies and material artifacts, rather than the deployment of one at a time. In just this way, Hodgkinson and Wright's (2002) case study shows how a CEO skillfully manages not only her discourse at the workshop, but also the lay-out of the chairs and her own bodily positioning vis-à-vis the whiteboard in order to ensure her control of the episode. Thus, research into strategy praxis needs to go beyond discourse to consider how the material, in the form of both bodies and artifacts, is used to accomplish strategy work. Here, video-ethnographic methods, capable of capturing both the material and the discursive, are likely to be particularly valuable (Liu \& Maitlis, forthcoming).

\section{Critical Analysis}

A fifth way to extend SAP research is to promote critical analysis of taken-for-granted practices. Practice-based analyzes can focus on any practices that are important to understand the phenomenon in question. However, it is precisely the "invisible", taken-for-granted practices that are arguably the most interesting objects for practice-based social analysis; for example, Garfinkel (1967, pp. 35-37) advocated making the socially mundane "analytically exotic" and Bourdieu spoke about the need to "make the exotic mundane and the mundane exotic" (Bourdieu \& Wacquant, 1992, p. 68). In this view, the point is not only to examine patterns in the activity of strategists (praxis) or the most apparent aspects of the practices involved (as most of SAP research has so far focused on), but to problematize these practices in order to capture the ways in which taken-for-granted assumptions condition strategizing and strategy-making.

This questioning of the taken-for-granted is particularly important to advance more critical analysis of strategy and strategizing (Carter, Clegg, \& Kornberger, 2008; Chia \& MacKay, 2007; McCabe, 2010). For instance, strategic management as a discipline arguably secretes within itself a neo-liberal ideology and corporate hegemony (Knights \& Morgan, 1991; Levy et al., 2003). While previous studies have highlighted the ideological aspects embedded in discourses of strategic planning (Hodge 
\& Coronado, 2006; Oakes et al., 1998), future studies could go further in unraveling the implications for organizational strategy-making. For instance, we need to better understand how conventional practices of strategic planning may legitimate and naturalize short-term profit-orientation, instrumentalism in how people are treated (often seen as resources rather than subjects), or neocolonialism in terms of dominance of western worldviews (celebrating choice and competition) over other cultural values. Moreover, it is important to focus attention on the ways in which such practices can be resisted locally or more widely. As mentioned above, resistance has so far received little attention in strategy research (Ezzamel \& Willmott, 2008; Laine \& Vaara, 2007; McCabe, 2010); however, it is only through an analysis of how people deal with practices imposed upon them that we can understand their full implications.

Strategic planning often promotes the role of top management and thereby effectively impedes organization-wide participation. As discussed above, this involves a myriad of discursive and sociomaterial practices that often pass unnoticed in organizations (Mantere \& Vaara, 2008; McCabe, 2010). It is important to go further in the analysis of how this takes place in various contexts as well as how inclusion or empowerment could be promoted. At the same time, we need to better understand the social construction of accountability and responsibility in strategy-making; for example, the implications for middle managers (Sillince \& Mueller, 2007). However, contemporary discourses about strategic participation, inclusion, and empowerment in and through strategy deserve critical attention in their own right. For instance, sometimes talk about participation may serve primarily to establish legitimacy or be used for ceremonial purposes. It can even involve hypocrisy; invitations to participate without a real possibility to voice concerns or influence strategic decisions. Moreover, involving people in strategy discourse can be seen as a form of subjugation where the participants are "seduced" to commit to goals and values that may not be in their interests (Allard-Poési, 2010).

Equality needs special attention in its own right; this is especially the case with gender. Strategic management seems to involve gendered aspects and promote masculine values in and through practices that easily pass unnoticed (Knights \& Morgan, 1991; Rouleau, 2005). Previous studies have shown that this involves the subtle use of vocabulary and rhetoric (Eriksson, Henttonen, \& Meriläinen, 2008; Samra-Fredericks, 2005); future research could go further in uncovering these practices and their implications. On the one hand, it would be interesting to better understand the special roles and identities that women (or men) play in strategy and strategizing in various contexts. These roles and identities may be different, but they will probably also greatly depend on organizational and institutional contexts. On the other, it would be important go further in the analysis of how exactly the very practices of strategizing promote specific identifications and patterns of action; for example, how masculine values embedded in strategy discourse make people behave accordingly. 
Finally, the practices of strategic planning may at times create a world of their own with all kinds of implications for the people involved. Indeed, we need a critical eye on the professionalization of strategic management and the industry it has become (Knights \& Morgan, 1991; Whittington et al., 2011). Grandy and Mills (2004) go as far as to suggest that strategic management discourses have created a hyperreality - that has little to do with the "real" organizational activities-that is nevertheless perceived as natural by the practitioners involved. Whether and to what extent this new hyperreality helps people to make sense of their future or contributes to alienation or illusion is an open question for future research. In a similar vein, it seems important to adopt a critical view on the fashions of strategic management, to study the ways in which these fashions are spread and to examine their implications on organizations (Abrahamson, 1996). Such critical reflection should also involve management education. It is important to analyze the ways in which management education spreads, legitimates, and naturalizes strategic management practices-and what that implies. For example, we should examine whether business schools or management education more generally—as sometimes argued-legitimate instrumentalism and even unethical behavior (Khurana, 2007; Mintzberg, 2004) or whether they help to promote inclusion and equality. Such issues are not easy to tackle in conventional studies of strategic management, but a close analysis of discursive and sociomaterial practices helps us to better understand the various effects that strategic management has on contemporary organizations and the people involved.

\section{Implications for Other Streams of Research}

We have argued that SAP research is in a unique position in the field of strategic management because of its ability to connect micro-level analysis with macro-level considerations, to bridge structure and agency in explaining strategic action, and to broaden the range of outcomes. Table 4 juxtaposes SAP with other-related approaches in strategic management as well as institutional theory. We shall focus below on the intersections with Strategy Process studies and the Micro-Foundations perspective on the one hand, and Macro-Institutional Theory and Institutional Work on the other.

\section{Strategy Process and Micro-Foundations}

SAP's roots lie partly in the classic process studies that have argued the importance of organizational politics, culture, and routines in strategic decision-making and change (Bower, 1982; Burgelman, 1983; Johnson, 1987; Mintzberg \& Waters, 1985; Pettigrew, 1985). The process complexities revealed in these and other studies have made the fundamental case for SAP researchers' close examination of how strategies are actually made. Of course, there are differences between Strategy Process and SAP as well (Table 4). The classic Process perspective has emphasized managerial agency in the form of individual managers or teams, whereas SAP is increasingly focusing on the structuring role of organizational and wider social practices. Similarly, SAP is less concerned with 
economic performance, embracing other outcomes such as practitioners' performance of their roles or the influence of particular practices or generic sets of actors.

Despite these differences, SAP and Strategy Process remain part of the same family and there are strong grounds for developing a shared agenda (Floyd, Cornelissen, Wright, \& Delios, 2011; Whittington, 2007). As we have seen, SAP researchers have made good progress in first rediscovering and then exploring strategic planning processes. There is less research so far on other key processes such as leadership or strategic change. The promise here is that, by focusing on concrete practices, SAP has the potential to demystify process concepts such as charismatic leadership or freezing and unfreezing in the management of change. Underneath, the veneer of charisma, SAP would expect to find quite standard practices of rhetorical discourse; behind successful change initiatives, SAP would look for such mundane practices as simple project management.

Grounds for a shared research agenda are strengthening further with the development of the "new Process Studies” perspective (Hernes \& Maitlis, 2010; Tsoukas, 2010; Tsoukas \& Chia, 2002). Particularly relevant to SAP's interest in praxis is the new Process perspective's ambition to capture underlying change mechanisms in action and in real time. By synthesizing the Processual sensitivity to change over time and the Practice perspective's concern for institutionalized social practices, there is the prospect of significantly advancing understanding of how dynamism and continuity combine in strategy emergence. In particular, this synthesis of the new Process and the SAP approaches can motivate further temporally-aware investigations into the ways in which actors both draw from and are constrained by discursive and socio-material practices in unfolding processes of strategy-making (Chia \& MacKay, 2007). The recent SAP attention to sequences of episodes over time offers one promising route for combining micro-level focus with processual evolution in the longer run (Aggerholm et al., forthcoming; Denis et al., 2011; Spee \& Jarzabkowski, 2011).

As Floyd and Sputtek (2011) have observed too, SAP's attention to micro-level praxis suggests an obvious affinity as well with the current interest in Micro-Foundations in strategy research (Eisenhardt et al., 2010; Felin \& Foss, 2005; Foss, 2011; Teece, 2007). The Micro-Foundations perspective seeks to root the origins of organizational advantage in the character of individuals and their interactions. As for other practice perspectives (Parmigiani \& Howard-Grenville, 2011), SAP can provide the Micro-Foundations domain with much-needed methods for researching organizational routines and capabilities. Regnér (2003, 2008) and Ambrosini et al. (2007) have already provided models for SAP-style investigation in these areas. However, despite the potential that these SAP studies suggest, the problem of organizational routines and capabilities has not yet become central to SAP researchers. For those wishing to connect SAP research more closely to the strategy discipline's core concern of organizational performance, contribution to the Micro-Foundations problematic is an 
open window of opportunity.

While recognizing the potential for more connection with Micro-Foundations research, we offer one warning. In some accounts, Micro-Foundations are associated strongly with methodological individualism (Foss, 2011). However, SAP researchers with a commitment to practices would refuse Felin and Foss's (2005) insistence that "organizations are made up of individuals", and the methodological prescription that one must always start with the individual. From a practice theory perspective, organizations are made up of practices, and it is practices that enable individuals in the first place. Starting with practices rather than individuals generates some distinctive propositions: for example, a focus on practices is likely to suggest that valuable capabilities are not wholly idiosyncratic to particular organizations, but the artful translation of generalized practices that exist across organizations. SAP thus has insights to contribute to Micro-Foundations precisely by avoiding methodological individualism.

One promising Micro-Foundational approach that is sensitive to the limitations of individualism is found in recent variants of Behavioral Strategy (Gavetti, 2012; Powell, Lovallo, \& Fox, 2011). Behavioral Strategy locates its Micro-Foundations in the imperfect mental processes of strategic leaders, especially with regard to the cognitively distant opportunities that are the typical objects of strategy. In this acceptance of cognitive imperfection, Behavioral Strategy clearly links with the stream of work on sensemaking and framing that has already appeared in SAP (Balogun \& Johnson, 2005; Kaplan, 2008). Moreover, although focused on individuals (“leaders”), Behavioral Strategy theorists do recognize the dangers of reductionism. Thus, Powell et al. (2011) propose a "contextualist" variant of Behavioral Strategy drawing on practice theorists such as Giddens and Foucault and entailing ethnographic and discourse analytic methodologies. Linking to such a contextualist approach offers SAP researchers a more natural allegiance than with methodological individualist variants of Micro-Foundations research. From a contextualist perspective, SAP would look to social practices (for example, culturally-legitimate discourses and procedures) as the source of cognitive bias, rather than purely mental processes.

\section{Institutional Analysis}

Institutional theories ought to be a natural source of inspiration for SAP researchers. Rejecting accounts based on rational individual calculus, institutional theorists generally explain behavior in terms of the social institutions in which actors are embedded (Greenwood, Oliver, Sahlin, \& Suddaby, 2008). The social is as close to the heart for institutional theorists as it is for practice theorists. Following Lawrence, Suddaby, and Leca (2011), we shall distinguish between Macro-Institutional Theory broadly conceived and a new perspective focused on Institutional Work. Macro-Institutional Theory is typically concerned with social institutions and change on a large-scale, while the 
Institutional Work perspective focuses on the agency of individual actors laboring day-to-day at maintaining and transforming institutions.

Macro-Institutional Theory has two points of empirical focus that are particularly relevant to SAP research: the diffusion of practices through organizations and societies and the evolution of fields, such as sectors or professions (Table 4). As we have seen, the institutionalist notion of "fields" as constellations of actors bound by repeated interaction and shared norms (Wooten \& Hoffman, 2008) is helpful in reconceiving strategy practitioners as not merely organizational actors but participants in a wider community that includes extra-organizational actors such as the media, consultants, and business school academics (Whittington et al., 2003). Understanding strategy as a field raises the characteristic questions of Macro-Institutional Theory, most of which remain under-explored so far by SAP researchers. For example, how did strategy first emerge as a proto-professional field in the 1960s and why has it failed to consolidate its professional status since then? How is the field of strategy changing today as strategy skills are devalued by the proliferation of MBA graduates and the commodification of strategy knowledge? What are the relative roles of strategy consulting firms, professional societies, and business schools in maintaining standards in the strategy field?

The second promising empirical focus for SAP relates to Macro-Institutional Theory's interest in the origins and diffusion of influential practices. As we have seen, Ghemawat (2002) has already raised concern about the role of strategy consulting firms in the creation and dissemination of innovative but untested strategy practices: he cites the exaggerated "new economy" ideas of the dot.com boom as salutary example. Some work is already beginning to link institutional theory and SAP with regard to new sectoral practices (Gomez \& Bouty, 2011; Lounsbury \& Crumley, 2007). There remain opportunities for research on the diffusion of strategic management practices with more general implications, especially on a comparative cross-sectoral and cross-national basis. In particular, MacroInstitutional Theory research on globalization (Drori, 2008) and national institutional effects (Boxenbaum \& Battilana, 2005; Hamilton \& Biggart, 1988) can contribute insight on the diffusion and translation of strategic management practices in new national contexts.

There is a close affinity too between SAP research and research on Institutional Work (Lawrence, Suddaby, \& Leca, 2009; Zietsma \& Lawrence, 2010). In particular, the Institutional Work themes of agents, activity, and institutions map closely onto the SAP model of practitioners, praxis, and practices. Moreover, the Institutional Work perspective's concern for institutional outcomes (Table 4) offers a powerful stimulus for more SAP research on the work and actors involved in producing particular strategy practices that gain influence on a large-scale. Examples might include the activities of the creators and promoters of influential recent tools such as "Blue Ocean Strategy" (Kim \& Maubourgne, 2005) or “Strategy Mapping” (Kaplan \& Norton, 2004). 
The Institutional Work perspective also offers the concept of "institutional biographies" as a means of treating individual agents without falling into the trap of methodological individualism (Suddaby \& Viale, 2011; Lawrence et al., 2011). “Institutional biography” draws on Bourdieu’s notion of social capital in order to emphasize how agents' trajectories through life (family, education, and career) have both exposed them to certain institutional norms and endowed them with institutional resources. The agent is thus not the expression of an individual will, but the carrier of a complex social institutional legacy, on which he or she must draw in their on-going institutional work. This concept of institutional biography has obvious application to SAP's concern with strategy practitioners. For example, there are research opportunities in exploring the characteristic institutional biographies of strategic planners or strategy consultants and how they shape particular kinds of praxis distinctive from agents with different biographies.

In short, both Macro-Institutional Theory and the Institutional Work tradition prompt new questions for SAP research and offer new conceptual tools to address them. One promising example that combines a practice sensibility with both Macro-Institutional Theory and Institutional Work is Smets et al.’s (forthcoming) study of a merger between British and German law firms. In their model, they show how differences in national institutional practices can be negotiated through the improvisations of everyday work, and then, once consolidated within an organization, finally impact the development of the field at a macro-level. This model differs from some earlier theories of institutional change in that it focuses attention on the detailed activities and practices that people in an organization are engaged in. Here, the appreciation of praxis and practitioners bears close resemblance to SAP research and provides an example of how practice-based and institutional level analyzes can complement each other.

\section{Conclusions}

We have argued in this article that practice-based approaches in general and SAP in particular deepen our understanding of strategy-making in and around organizations. SAP research has brought social theories into strategic management, it has extended the concept of performance, it has broadened the range of organizations studied, and it has applied and developed qualitative methods to explore details of strategy with hitherto unappreciated significance. SAP research has revealed a variety of practices that have significant enabling and constraining effects on strategy-making, many of which have been overlooked in mainstream research. Analyzes of praxis have shown how strategy-making is performed in episodes over time and how actors' skills in dealing with practices may have a decisive impact on the outcomes. Finally, SAP research has also demonstrated the variety of actors that may engage in strategy-making, while recognizing how the discourses of strategy also define who is in and who is out. 
The first decade has been productive, therefore, but there is a full agenda for SAP research going forwards as well. We have especially argued for more analysis of agency as placed in a web of social and discursive practices. Here, we have particularly emphasized the potential importance of macroinstitutional practices transcending organizational boundaries. We see scope too for going deeper into the issue of emergence in strategy-making. There are opportunities also in delving further into the material aspects of social practices. Finally, new insights can be generated by critical analysis of the taken-for-granted aspects of social practices. While there are certainly other important issues to be considered in future research, we believe that these directions will help significantly to advance SAP in the next generation of research.

By going in these directions, SAP research can also better connect to other streams of research in both strategic management and institutional theory. In strategic management, SAP-inspired studies can draw from the various sociological theories and methods that have so far played a limited role in the disciplinary mainstream. SAP research can benefit from the insights of institutional analysis, but it can also bring with it theoretical and methodological tools that are particularly well equipped to analyze institutional work at the micro-level.

By putting practices and practitioners in the center, SAP research promises to help in management research’s quest for practical relevance (Jarzabkowski, Mohrman, \& Scherer, 2010; Rynes, 2007). This relevance is not automatic, but will be enhanced by close engagement with practitioners, for instance through the kinds of action research and collaboration epitomized by some of the studies highlighted here (Angwin et al., 2009; Heracleous \& Jacobs, 2008). The value to practitioners will often come more through prompts to practitioner reflection than direct prescriptions (Splitter \& Seidl, 2011). An implication of the practice perspective, after all, is that skilled performance involves improvisation around practices rather than strict adhesion. However, SAP research can have a broader kind of relevance as well. Critical analyzes of strategic management are already beginning to elucidate the causes and consequences of the spread of strategy's practices and discourses (Knights \& Morgan, 1991; Whittington, 2010). These practices and discourses have wide and sometimes pernicious effects, extending far beyond particular organizations. SAP is relevant in the second sense, therefore, of helping to better understand issues in society. Thus, SAP research is in a unique position to provide knowledge that has broader relevance than studies in strategic management typically offer.

We have so far focused on how the SAP research agenda can be expanded. We have indicated underexplored issues, emphasized a wide range of theories and methods, and encouraged links with various other streams of research. Nevertheless, there are boundaries that SAP should be sensitive to. Particularly, if it takes a "theoretical" or "philosophical" approach to practice (Feldman \& 
Orlikowski, 2011), SAP research should always be careful to place strategy-making in organizational and institutional contexts. This is the fundamental difference between SAP and many conventional approaches to strategic management-including recent perspectives such as the Micro-Foundations approach - that build upon individualism and gives little attention to how the social guides, enables, and constrains what strategists do. SAP is about taking social practices seriously.

Finally, all this implies special challenges for scholars conducting SAP research. It is difficult to be close to the practitioners and at the same time apply complex social theories. It is demanding to study the micro-level while aiming at understanding the macro. It is hard to hang on to practical relevance while promoting a critical spirit. Yet, the rewards of meeting these challenges are great and, in the exemplary studies we feature here, there are plenty of research tools to help. Ultimately, the key issue in practice-based research is reflexivity: to be able to constantly reflect upon the enabling and constraining effects of social practices and to focus special attention on what is easily taken-forgranted by researchers and practitioners alike.

\section{Acknowledgements}

We are indebted to Royston Greenwood for his excellent guidance. We also want to express our gratitude to May Lönnholm and Tina Karme for helping us with the review of previous research and Pikka-Maaria Laine, Saku Mantere, David Seidl and Carola Wolf for insightful comments on the manuscript.

\section{Endnote}

1. Our criteria for inclusion are somewhat strict. First, we included only articles appearing in SAP special issues or with explicit and substantial reference to the SAP literature; we leave aside a number of important empirical articles without such reference but which still treat themes close to SAP (Balogun \& Johnson, 2004; Howard-Grenville, 2007; Rindova, Dalpiaz, \& Ravasi, 2011; Vaara \& Tienari, 2008). Second, we draw from journals ranked by the Association of Business School at 3 or 4, adding only Strategic Organization as a rising journal that has been particularly influential in SAP research. Our review is not exhaustive, therefore, and we regretfully exclude a number of valuable studies that are published in book form, in other journals or in languages other than English.

\section{References}

Abrahamson, E. (1996). Management fashion. Academy of Management Review, 2(1), 254 - 285.

Aggerholm, H.K., Asmuß, B., \& Thomsen, C. (forthcoming). The role of recontextualization for the multivocal, ambiguous process of strategizing. Journal of Management Inquiry, forthcoming 2012. 
Ahrens, T., \& Chapman, C.S. (2006). Doing qualitative field research in management accounting: Positioning data to contribute to theory. Accounting, Organizations and Society, 31(8), 819-841.

Allard-Poési, F. (2010). A Foucaldian perspective on strategic practice: Strategy as the art of (un)folding. In D. Golsorkhi, D. Seidl, L. Rouleau, \& E. Vaara (Eds.), The Cambridge handbook of strategy as practice (pp. 168 - 182). Cambridge: Cambridge University Press.

Alvesson, M., \& Kärreman, D. (2000). Varieties of discourse: On the study of organizations through discourse analysis. Human Relations, 53(9), 1125-1149.

Ambrosini, V., Bowman, C., \& Burton-Taylor, S. (2007). Inter-team coordination activities as a source of customer satisfaction. Human Relations, 60(1), 59-98.

Angwin, D., Paroutis, S., \& Mitson, S. (2009). Connecting up strategy: Are senior strategy directors (SSDs) a missing link? California Management Review, 51(3), 74-94.

Ansoff, I. (1965). Corporate strategy. New York, NY: McGraw-Hill.

Balogun, J., Jarzabkowski, P., \& Vaara, E. (2011). Selling, resistance and reconciliation: A critical discursive approach to subsidiary role evolution in MNCs. Journal of International Business Studies, 42, 765-786.

Balogun, J., \& Johnson, G. (2004). Organizational restructuring and middle managers sensemaking. Academy of Management Journal, 47(4), 523-549.

Balogun, J., \& Johnson, G. (2005). From intended strategies to unintended outcomes: The impact of change recipient sensemaking. Organization Studies, 26(11), 1573 - 1601.

Boje, D.M. (2008). Storytelling organizations. London: Sage Publications.

Bourdieu, P. (1990). The logic of practice. Cambridge: Polity Press.

Bourdieu, P., \& Wacquant, L. (1992). An invitation to reflexive sociology. Cambridge: Polity Press.

Bower, J.L. (1982). Managing the resource allocation process. Boston, MA: Harvard Business School Press.

Boxenbaum, E., \& Battilana, J. (2005). Importation as innovation: Transposing managerial practices across fields. Strategic Organization, 3(4), 1-29.

Brown, J.S., \& Duguid, P. (2001). Knowledge and organization: A social-practice perspective. Organization Science, 12(2), 198-213.

Burgelman, R.A. (1983). A process model of internal corporate venturing in the diversified major firm. Administrative Science Quarterly, 28(2), 223-244.

Cabantous, L., Gond, J.P., \& Johnson-Cramer, M. (2010). Decision theory as practice: Crafting rationality in organizations. Organization Studies, 31(11), 1531-1566.

Callon, M., \& Law, J. (1997). After the individual in society: Lessons on collectivity from science, technology and society. Canadian Journal of Sociology, 22, 165-182.

Carter, C.R., Clegg, S., \& Kornberger, M. (2008). Strategy as practice? Strategic Organization, 6(1), 83-99.

de Certeau, M. (1984). The practice of everyday life. Berkeley, CA: University of California Press.

Chia, R., \& Holt, R. (2006). Strategy as practical coping: A Heideggerian perspective. Organization Studies, 27(5), 635-655.

Chia, R., \& Holt, R. (2009). Strategy without design: The silent efficacy of indirect action.

Cambridge: Cambridge University Press.

Chia, R., \& MacKay, B. (2007). Post-processual challenges for the emerging strategy-as-practice perspective: Discovering strategy in the logic of practice. Human Relations, 60(1), 217-242.

Chia, R., \& Rasche, A. (2010). Building and dwelling world-views-Two alternatives for researching 
strategy as practice. In D. Golsorkhi, D. Seidl, L. Rouleau, \& E. Vaara (Eds.), Cambridge handbook of strategy as practice (pp. 34-46). Cambridge: Cambridge University Press.

Clarke, I., Kwon, W., \& Wodak, R. (2011). A context sensitive approach to analysing talk in management meetings: The discourse historical approach to critical discourse analysis. British Journal of Management, early view published online 27 Sept.

Cooren, F. (2010). Action and agency in dialogue: Passion, incarnation and ventriloquism. Amsterdam, PA: John Benjamins.

David, R.J., \& Strang, D. (2006). When fashion is fleeting: Transitory collective beliefs and the dynamics of TQM consulting. Academy of Management Journal, 49(2), 215 - 233.

Denis, J., Dompierre, G., Langley, A., \& Rouleau, L. (2011). Escalating indecision: Between reification and strategic ambiguity. Organization Science, 22(1), 225 - 244.

Drori, G.S. (2008). Institutionalism and globalization studies. In R. Greenwood, C. Oliver, K. Sahlin, \& R. Suddaby (Eds.), Handbook of organizational institutionalism (pp. 798-842). Thousand Oaks, CA: Sage.

Eisenhardt, K.M., \& Bourgeois, L.J. (1988). Politics of strategic decision-making in high-velocity environments: Toward a midrange theory. Academy of Management Journal, 31(4), 737-770.

Eisenhardt, K.M., Furr, N.R., \& Bingham, C.B. (2010). Micro-foundations of performance: Balancing efficiency and flexibility in dynamic environments. Organization Science, 21(6), 1263-1273.

Engeström, Y., Miettinen, R., \& Punamäki, R.-L. (Eds.). (1999). Perspectives on activity theory. Cambridge: Cambridge University Press.

Eppler, M.J., \& Platts, K.W. (2009). Visual strategizing: The systematic use of visualization in the strategic-planning process. Long Range Planning, 42, 42-74.

Eriksson, P., Henttonen, E., \& Meriläinen, S. (2008). The growth strategies of women-controlled SMEs: A case study on Finnish software companies. International Journal of Business Excellence, 1(4), 434-447.

Ezzamel, M., \& Willmott, H. (2008). Strategy as discourse in a global retailer: A supplement to rationalist and interpretive accounts. Organization Studies, 29(2), 191 - 217.

Ezzamel, M., \& Willmott, H. (2010). Strategy and strategizing: A poststructuralist perspective. Advances in Strategic Management, 27, 75-109.

Fairclough, N. (2003). Analyzing discourse: Textual analysis for social research. London: Routledge.

Fauré, B., \& Rouleau, L. (2011). The strategic competence of accountants and middle managers in budget making. Accounting, Organization and Society, 36, 167-182.

Feldman, M.S., \& Orlikowski, W.J. (2011). Theorizing practice and practicing theory. Organization Science, 22(5), 1240-1253.

Felin, T., \& Foss, N.J. (2005). Strategic organization: A field in search of micro-foundations. Strategic Organization, 3, 441-455.

Fenton, C., \& Langley, A. (2011). Strategy as practice and the narrative turn. Organization Studies, 32(9), 1171-1196.

Floyd, S.W., Cornelissen, M.W., Wright, M., \& Delios, A. (2011). Processes and practices of strategizing and organizing: Review, development and the role of bridging and umbrella constructs. Journal of Management Studies, 48(5), 933-952.

Floyd, S.W., \& Sputtek, R. (2011). Rediscovering the individual in strategy: Methodological challenges, strategies, and prospects. In D.D. Bergh \& D.J. Ketchen (Eds.), Building methodological bridges (Research Methodology in Strategy and Management, Vol. 6 pp. 3 - 30). Bingley: Emerald Group Publishing Limited. 
Floyd, S.W., \& Wooldridge, B. (2000). Building strategy from the middle. London: Sage.

Ford, J.D., Ford, L.W., \& D’Amelio, A. (2008). Resistance to change: The rest of the story. Academy of Management Review, 33(2), 362-377.

Foss, N. (2011). Why micro-foundations for resource-based theory are needed and what they may look like. Journal of Management, 37, 1413-1428.

Foucault, M. (1977). Discipline and punish. The birth of the prison. London: Penguin Books.

Foucault, M. (1980). Power/knowledge: Selected interviews and other writings, 1972-1977. New York: Pantheon Books.

Foucault, M. (1994). In J.D. Faubion (Ed.), Power: Essential works of Foucault, 1954-1984 (Vol. III). New York: The New York Press.

Freeland, R. (2001). The struggle for control of the modern corporation: Organizational change at General Motors, 1924-1970. Cambridge: Cambridge University Press.

Furrer, O., Thomas, H., \& Goussevskaia, A. (2008). The structure and evolution of the strategic management field: A content analysis of 26 years of strategic management research. International Journal of Management Reviews, 10(1), 1-23.

Garfinkel, H. (1967). Studies in ethnomethodology. Englewood Cliffs, NJ: Prentice-Hall.

Gavetti, G. (2012). Toward a behavioral theory of strategy. Organization Science, 23(1), 267 - 285.

Ghemawat, P. (2002). Competition and business strategy in historical perspective. Business History Review, 76(1), 37-47.

Gherardi, S. (2009). Introduction: The critical power of the "practice lens”. Management Learning, 40(2), 115-128.

Giddens, A. (1984). The constitution of society. Oxford: Polity Press.

Gioia, D.A., \& Chittipeddi, K. (1991). Sensemaking and sensegiving in strategic change initiation. Strategic Management Journal, 12(6), 433-448.

Giraudeau, M. (2008). The drafts of strategy: Opening up plans and their uses. Long Range Planning, 41(3), 291-308.

Goffman, E. (1959). The presentation of self in everyday life. New York: Doubleday, Anchor Books.

Golsorkhi, D., Rouleau, L., Seidl, D., \& Vaara, E. (Eds.). (2010). Cambridge handbook of strategy as practice. Cambridge: Cambridge University Press.

Gomez, M.L. (2010). A Bourdesian perspective on strategy-as-practice. In D. Golsorkhi, L. Rouleau, D. Seidl, \& E. Vaara (Eds.), Cambridge handbook of strategy as practice (pp. 141-155). Cambridge: Cambridge University Press.

Gomez, M.L., \& Bouty, I. (2011). The emergence of an influential practice: Food for thought. Organization Studies, 32(7), 921-940.

Grandy, G., \& Mills, A.J. (2004). Strategy as simulacra? A radical reflexive look at the discipline and practice of strategy. Journal of Management Studies, 41(7), 1153 - 1170.

Greenwood, R., Oliver, C., Sahlin, K., \& Suddaby, R. (Eds.). (2008). Introduction. The Sage handbook of organizational institutionalism (pp. 1-46). London: Sage.

Gross, N. (2009). A pragmatist theory of social mechanisms. American Sociological Review, 74(3), 358-379.

Hamilton, G., \& Biggart, N. (1988). Market, culture and authority: A comparative analysis of organization and management in the Far East. In C. Winship \& S. Rosen (Eds.), Organizations and institutions, American Journal of Sociology, 94(Suppl.), 52-94.

Hardy, C., Palmer, I., \& Phillips, N. (2000). Discourse as a strategic resource. Human Relations, 
53(9), 1227-1248.

Heidegger, M. (1962). Being and time. Oxford: Blackwell.

Hendry, J. (2000). Strategic decision making, discourse and strategy as social practice. Journal of Management Studies, 37(7), 955-977.

Hendry, K.P., Kiel, J.C., \& Nicholson, G. (2010). How boards strategise: A strategy as practice view. Long Range Planning, 43, 33-56.

Hendry, J., \& Seidl, D. (2003). The structure and significance of strategic episodes: Social systems theory and the routine practices of strategic change. Journal of Management Studies, 40(1), 175-196.

Heracleous, L., \& Jacobs, C.D. (2008). Crafting strategy: The role of embodied metaphors. Long Range Planning, 41, 309-325.

Heracleous, L., \& Jacobs, C.D. (2011). Crafting strategy: Embodied metaphors in practice. Cambridge: Cambridge University Press.

Hernes, T., \& Maitlis, S. (Eds.). (2010). Process, sensemaking, \& organizing. Oxford: Oxford University Press.

Hill, T., \& Westbrook, R. (1997). SWOT analysis: It’s time for a product recall. Long Range Planning, 30(1), 46-52.

Hodge, B., \& Coronado, G. (2006). Mexico Inc.? Discourse analysis and the triumph of managerialism. Organization, 13(4), 529-547.

Hodgkinson, G., Whittington, R., Johnson, G., \& Schwarz, M. (2006). The role of strategy workshops in strategy development processes: Formality, communication, co-ordination and inclusion. Long Range Planning, 39(5), 479-496.

Hodgkinson, G.P., \& Wright, G. (2002). Confronting strategic inertia in a top management team: Learning from failure. Organization Studies, 23(6), 949-976.

Hoon, C. (2007). Committees as strategic practice: The role of strategic conversation in a public administration. Human Relations, 60(6), 921-952.

Howard-Grenville, J.A. (2007). Developing issue-selling effectiveness over time: Issue selling as resourcing. Organization Science, 18(4), 560-577.

Jarratt, D., \& Stiles, D. (2010). How are methodologies and tools framing managers' strategizing practice in competitive strategy development? British Journal of Management, 21, 28-43.

Jarzabkowski, P. (2003). Strategic practices: An activity theory perspective on continuity and change. Journal of Management Studies, 40(1), 23-55.

Jarzabkowski, P. (2005). Strategy as practice. London: Sage.

Jarzabkowski, P. (2008). Shaping strategy as a structuration process. Academy of Management Journal, 51(4), 621-650.

Jarzabkowski, P., \& Balogun, J. (2009). The practice and process of delivering integration through strategic planning. Journal of Management Studies, 46(8), 1255 - 1288.

Jarzabkowski, P., Balogun, J., \& Seidl, D. (2007). Strategizing: The challenges of a practice perspective. Human Relations, 60(1), 5-27.

Jarzabkowski, P., \& Fenton, E. (2006). Strategizing and organizing in pluralistic contexts. Long Range Planning, 39, 631-648.

Jarzabkowski, P., Mohrman, S.A., \& Scherer, A.G. (2010). Organization studies as applied science: The generation and use of academic knowledge about organizations. Introduction to the Special Issue. Organization Studies, 31(9 \& 10), 1189 - 1207.

Jarzabkowski, P., \& Seidl, D. (2008). The role of meetings in the social practice of strategy. 
Organization Studies, 29(11), 1391-1426.

Jarzabkowski, P., \& Spee, P. (2009). Strategy as practice: A review and future directions for the field. International Journal of Management Reviews, 11(1), 69-95.

Jarzabkowski, P., \& Wilson, D.C. (2002). Top teams and strategy in a UK university. Journal of Management Studies, 39(3), 355-387.

Johnson, G. (1987). Strategic change and the management process. Oxford: Blackwell.

Johnson, G., Melin, L., \& Whittington, R. (2003). Guest editor’s introduction. Micro-strategy and strategizing: Towards an activity-based view. Journal of Management Studies, 40(1), 3-22.

Johnson, G., Prashantham, S., Floyd, S.W., \& Bourque, N. (2010). The ritualization of strategy workshops. Organization Studies, 31(12), 1589-1618.

Jørgensen, B., \& Messner, M. (2010). Accounting and strategising: A case study from new product development. Accounting, Organizations and Society, 35(2), 184 - 204.

Kaplan, S. (2008). Framing contests: Strategy-making under uncertainty. Organization Science, 19(5), 729-752.

Kaplan, S. (2011). Strategy and PowerPoint: An inquiry into the epistemic culture and machinery of strategy-making. Organization Science, 22(2), 320-346.

Kaplan, R.S., \& Norton, D.P. (2004). Strategy maps: Converting intangible assets into tangible outcomes. Boston, MA: Harvard Business School Publishing Corporation.

Ketchen, D.J., Boyd, B.K., \& Bergh, D.D. (2008). Research methodology in strategic management: Past accomplishments and future challenges. Organizational Research Methods, 11(4), 643-658.

Khurana, R. (2007). From higher aims to hired hands: The social transformation of American business schools and the unfulfilled promise of management as profession. Princeton, NJ: Princeton University Press.

Kim, W.C., \& Maubourgne, R. (2005). Blue Ocean Strategy: How to create uncontested market space and make the competition irrelevant. Boston, MA: Harvard Business School Publishing Corporation.

Knights, D., \& Morgan, G. (1991). Corporate strategy, organisations and subjectivity: A critique. Organization Studies, 12(2), 251-273.

Korkman, O., Storbacka, K., \& Harald, B. (2010). Practices as markets: Value co-creation in einvoicing. Australasian Marketing Journal, 18, 236-247.

Kornberger, M., \& Clegg, S. (2011). Strategy as performative practice: The case of Sydney 2030. Strategic Organization, 9(2), 136-162.

Laine, P.-M., \& Vaara, E. (2007). Struggling over subjectivity: A discursive analysis of strategic development in an engineering group. Human Relations, 60(1), 29-58.

Lampel, J., \& Baum, J.A.C. (2010). The globalization of strategic management research: Permanent pluralism or prelude to a new synthesis? In J.A.C. Baum \& J. Lampel (Eds.), The globalization of strategy research (Advances in Strategic Management, Vol. 27) (pp. xiii-xxxii). Oxford: JAI/Emerald.

Langley, A. (1989). In search of rationality: The purposes behind the use of formal analysis in organizations. Administrative Science Quarterly, 34(4), 598-631.

Latour, B. (2005). Reassembling the social: An introduction to actor-network-theory. Cambridge: Oxford University Press.

Lawrence, T.B., Suddaby, R., \& Leca, B. (2009). Introduction: Theorizing and studying institutional work. In T.B. Lawrence, R. Suddaby, \& B. Leca (Eds.), Institutional work: Actors and agency in institutional studies of organizations (pp. 1-27). Cambridge: Cambridge University Press.

Lawrence, T., Suddaby, R., \& Leca, B. (2011). Institutional work: Refocusing institutional studies of organization. Journal of Management Inquiry, 20(1), 52-58. 
Levina, N., \& Orlikowski, W.J. (2009). Understanding shifting power relations within and across fields of practice: A critical genre analysis. Academy of Management Journal, 52(4), 672-703.

Levy, D.L., Alvesson, M., \& Willmott, H. (2003). Critical approaches to strategic management. In M. Alvesson \& H. Willmott (Eds.), Studying management critically (pp. 92-110). London: Sage.

Liu, F., \& Maitlis, S. (Forthcoming). Emotional dynamics and strategizing processes: A study of strategic conversations in top team meetings. Journal of Management Studies, forthcoming 2012.

Lounsbury, M., \& Crumley, E. (2007). New practice creation: An institutional perspective on innovation. Organization Studies, 28(7), 993-1012.

Lounsbury, M., \& Hirsch, P.M. (Eds.). (2010). Markets on trial: The economic sociology of the U.S. financial crisis. New York: Emerald Press/MacMillan, Vol. 30B of Research in the Sociology of Organizations.

MacKenzie, D. (2006). An engine, not a camera. Cambridge, MA: The MIT Press.

Maitlis, S., \& Lawrence, T.B. (2003). Orchestral manoeuvres in the dark: Understanding failure in organizational strategizing. Journal of Management Studies, 40(1), 109 - 139.

Mantere, S. (2005). Strategic practices as enablers and disablers of championing activity. Strategic Organization, 3(2), 157-184.

Mantere, S. (2008). Role expectations and middle managers strategic agency. Journal of Management Studies, 45(2), 294-316.

Mantere, S., \& Vaara, E. (2008). On the problem of participation in strategy: A critical discursive perspective. Organization Science, 19(2), 341-358.

McCabe, D. (2010). Strategy-as-power: Ambiguity, contradiction and the exercise of power in a UK building society. Organization, 17(2), 151-175.

Miettinen, R., Samra-Fredericks, D., \& Yanow, D. (2009). Return to practice: An introductory essay. Organization Studies, 30(12), 1309-1327.

Mintzberg, H. (1994). The rise and fall of strategic planning. New York: Free Press.

Mintzberg, H. (2004). Managers not MBAs: A hard look at the soft practice of managing and management development. San Francisco, CA: Berrett-Koehler.

Mintzberg, H., \& Waters, J. (1985). Of strategies deliberate and emergent. Strategic Management Journal, 6(3), 257-272.

Moisander, J., \& Stenfors, S. (2009). Exploring the edges of the theory-practice gap: Epistemic cultures in strategy-tool development and use. Organization, 16(2), 227 - 247.

Molina-Azorin, J.F. (2009). Understanding how mixed methods research is undertaken within a specific research community: The case of business studies. International Journal of Multiple Research Approaches, 3(1), 47-57.

Molloy, E., \& Whittington, R. (2005). Organising organising: The practice inside the process. Advances in Strategic Management, 22, 491-515.

Nag, R., Hambrick, D.C., \& Chen, M.-J. (2007). What is strategic management, really? Inductive derivation of a consensus definition of the field. Strategic Management Journal, 28, 935-955.

Nordqvist, M. (2012). Understanding strategy processes in family firms: Exploring the roles of actors and arenas. International Small Business Journal, 30(1), 24-40.

Nordqvist, M., \& Melin, L. (2008). Strategic planning champions: Social craftspersons, artful interpreters and known strangers. Long Range Planning, 41(3), 326-344.

Oakes, L.S., Townley, B., \& Cooper, D.J. (1998). Business planning as pedagogy: Language and control in a changing institutional field. Administrative Science Quarterly, 43(2), 257-292. 
O’Brien, F. (2011). Supporting the strategy process: A survey of UK OR/MS practitioners. Journal of the Operational Research Society, 62, 900-920.

Ocasio, W., \& Joseph, J. (2008). Rise and fall—or transformation? The evolution of strategic planning at the General Electric Company. Long Range Planning, 41, 248 - 272.

Orlikowski, W.J. (2007). Sociomaterial practices: Exploring technology at work. Organization Studies, 28, 1435-1448.

Orlikowski, W.J. (2010). Engaging practice in research: Phenomenon, perspective, and philosophy. In D. Golsorkhi, L. Rouleau, D. Seidl, \& E. Vaara (Eds.), Cambridge handbook of strategy as practice (pp. 23-33). Cambridge: Cambridge University Press.

Orlikowski, W.J., \& Yates, J. (1994). Genre repertoire: Examining the structuring of communicative practices in organizations. Administrative Science Quarterly, 39, 541 - 574.

O’Shea, J., \& Madigan, C. (1997). Dangerous company: The consulting powerhouses and the businesses they save and ruin. New York: Random House.

Palmisano, S. (2004). Leading change when business is good. Interview by Paul Hemp and Thomas A. Stewart. Harvard Business Review, 82(12), 60-70.

Parmigiani, A., \& Howard-Grenville, J. (2011). Routines revisited: Exploring the capabilities and practice perspectives. Academy of Management Annals, 5, 413-453.

Paroutis, S., \& Pettigrew, A. (2007). Strategizing in the multi-business firm: Strategy teams at multiple levels and over time. Human Relations, 60(1), 99-135.

Pettigrew, A.M. (1973). The politics of organizational decision-making. London: Tavistock Publications.

Pettigrew, A.M. (1985). The awakening giant. Oxford: Basil Blackwell.

Phelan, S.E., Ferreira, M., \& Salvador, R. (2002). The first twenty years of the strategic management journal. Strategic Management Journal, 23(12), 1161-1168.

Phillips, N., Sewell, G., \& Jaynes, S. (2008). Applying critical discourse analysis in strategic management research. Organizational Research Methods 11(4), 770-789.

Piderit, S.K. (2000). Rethinking resistance and recognizing ambivalent attitudes toward organizational change: A multidimensional view. Academy of Management Review, 25(4), 783-794.

Porter, M.E. (1980). Competitive strategy. New York: Free Press. Porter, M.E. (1986). Competition in global industries: A conceptual framework. In M.E. Porter (Ed.), Competition in global industries. Boston, MA: Harvard Business School Press.

Powell, T.C., Lovallo, D., \& Fox, C. (2011). Behavioral strategy. Strategic Management Journal, 32(13), 1369-1386.

Ramos-Rodríguez, A-R., \& Ruíz-Navarro, J. (2004). Changes in the intellectual structure of strategic management research: A bibliometric study of the Strategic Management Journal, 1980 - 2000. Strategic Management Journal, 25(10), 981 - 1004.

Reckwitz, A. (2002). Toward a theory of social practices: A development in cultural theorizing. European Journal of Social Theory, 5(2), 243-263.

Regnér, P. (2003). Strategy creation in the periphery: Inductive versus deductive strategy-making. Journal of Management Studies, 40(1), 57-82.

Regnér, P. (2008). Strategy-as-practice and dynamic capabilities: Steps towards a dynamic view of strategy. Human Relations, 61(4), 565-588.

Rindova, V., Dalpiaz, E., \& Ravasi, D. (2011). A cultural quest: A study of organizational use of new cultural resources in strategy formation. Organization Science, 22(2), $413-431$.

Robichaud, D., Giroux, H., \& Taylor, J. (2004). The metaconversation: The recursive property of 
language as a key to organizing. Academy of Management Review, 29, 617-634.

Ronda-Pupo, G.A., \& Guerras-Martin, L.A. (2011). Dynamics of the evolution of the strategy concept 1962 - 2008: A co-word analysis. Strategic Management Journal, 33(2), 168-188.

Rouleau, L. (2005). Micro-practices of strategic sensemaking and sensegiving: How middle managers interpret and sell change every day. Journal of Management Studies, 42(7), 1414-1441.

Rouleau, L., Allard-Poési, F., \& Warnier, V. (2007). Le management stratégique en pratiques. Revue Française de Gestion, 33(174), 15-24.

Rouleau, L., \& Balogun, J. (2011). Middle managers, strategic sensemaking, and discursive competence. Journal of Management Studies, 48(5), 953-983.

Rouse, J. (2007). Practice philosophy. In S. Turner \& M. Risjord (Eds.), Handbook of the philosophy of science (Vol. 15): Philosophy of anthropology and sociology. London: Elsevier.

Rynes, S.L. (2007). Let's create a tipping point: What academics and practitioners can do, alone and together. Academy of Management Journal, 50, 1046-1054.

Salvato, C. (2003). The role of micro-strategies in the engineering of firm evolution. Journal of Management Studies, 40(1), 83-108.

Samra-Fredericks, D. (2003). Strategizing as lived experience and strategists' everyday efforts to shape strategic direction. Journal of Management Studies, 40(1), 141 - 174.

Samra-Fredericks, D. (2005). Strategic practice, “discourse” and the everyday interactional constitution of "power effects. Organization, 12(6), 803-841.

Samra-Fredericks, D. (2010). Researching everyday practice: The ethnomethodological contribution. In D. Golsorkhi, L. Rouleau, D. Seidl, \& E. Vaara (Eds.), Cambridge handbook of strategy as practice (pp. 230 - 242). Cambridge: Cambridge University Press.

Schatzki, T.R., Knorr-Cetina, K., \& von Savigny, E. (Eds.). (2001). The practice turn in contemporary theory. London: Routledge.

Seidl, D. (2007). General strategy concepts and the ecology of strategy discourses: A systematicdiscursive perspective. Organization Studies, 28(2), 197-218.

Sillince, J., Jarzabkowski, P., \& Shaw, D. (2011). Shaping strategic action through the rhetorical construction and exploitation of ambiguity. Organization Science, early view published online June 2011.

Sillince, J., \& Mueller, F. (2007). Switching strategic perspective: The reframing of accounts of responsibility. Organization Studies, 28(2), 155-176.

Smets, M., Morris, T., \& Greenwood, R. (forthcoming). From practice to field: A multi-level model of practice-driven institutional change. Academy of Management Journal, forthcoming 2012.

Spee, A.P., \& Jarzabkowski, P. (2009). Strategy tools as boundary objects. Strategic Organization, 7(2), 223-232.

Spee, A.P., \& Jarzabkowski, P. (2011). Strategic planning as communicative process. Organization, 32(9), 1217-1245.

Splitter, V., \& Seidl, D. (2011). Does practice-based research on strategy lead to practically relevant knowledge? Implications of a Bourdieusian perspective. Journal of Applied Behavioral Science, 47(1), 98-120.

Stensaker, I., \& Falkenberg, J. (2007). Making sense of different responses to corporate change. Human Relations, 60(1), 137-178.

Streeck, J., Goodwin, C., \& LeBaron, C. (Eds.). (2011). Embodied interaction: Language and body in the material world. Cambridge: Cambridge University Press.

Suddaby, R., \& Viale, T. (2011). Professionals and field-level change: Institutional work and the 
professional project. Current Sociology, 59(4), 423-442.

Suominen, K., \& Mantere, S. (2010). Consuming strategy: The art and practice of managers' everyday strategy usage. Advances in Strategic Management, 27, 211 - 245.

Teece, D.J. (2007). Explicating dynamic capabilities: The nature and micro-foundations of (sustainable) enterprise performance. Strategic Management Journal, 28(13), 1319 - 1350.

Tengblad, S. (2012). The work of managers: Towards a practice theory of management. Oxford University Press.

Thomas, R., Sargent, L., \& Hardy, C. (forthcoming). Managing organizational change: Negotiating meaning and power-resistance relations. Organization Science.

Tsoukas, H. (2010). Practice, strategy-making and intentionality: A Heideggerian onto-epistemology for strategy as practice. In D. Golsorkhi, L. Rouleau, D. Seidl, \& E. Vaara (Eds.), Cambridge handbook of strategy as practice (pp. 47-62). Cambridge: Cambridge University Press.

Tsoukas, H., \& Chia, R. (2002). On organizational becoming: Rethinking organizational change. Organization Science, 13(3), 567-582.

Vaara, E. (2010). Taking the linguistic turn seriously: Strategy as multifaceted and inter-discursive phenomenon. Advances in Strategic Management, 27, 29-50.

Vaara, E., Kleymann, B., \& Seristö, H. (2004). Strategies as discursive constructions: The case of airline alliances. Journal of Management Studies, 41(1), 1-35.

Vaara, E., Sorsa, V., \& Pälli, P. (2010). On the force potential of strategy texts: A critical discourse analysis of a strategic plan and its power effects in a city organization. Organization, 17(6), 685-702.

Vaara, E., \& Tienari, J. (2008). A discursive perspective on legitimation strategies in MNCs. Academy of Management Review, 33(4), 985-993.

Vaara, E., \& Tienari, J. (2011). On the narrative construction of MNCs: An antenarrative analysis of legitimation and resistance in a cross-border merger. Organization Science, 22(2), 370-390.

Vygotsky, L. (1978). Mind in society: The development of higher psychological processes. Cambridge, MA: Harvard University Press.

Whittington, R. (1996). Strategy as practice. Long Range Planning, 29(5), 731-735. Whittington, R. (2006). Completing the practice turn in strategy research. Organization Studies, 27(5), 613-634.

Whittington, R. (2007). Strategy practice and strategy process: Family differences and the sociological eye. Organization Studies, 28(10), 1575-1586.

Whittington, R. (2010). Giddens, structuration theory and strategy-as-practice. In D. Golsorkhi, L. Rouleau, D. Seidl, \& E. Vaara (Eds.), Cambridge handbook of strategy as practice (pp. 109-126). Cambridge: Cambridge University Press.

Whittington, R. (2011). The practice turn in organization research: Towards a disciplined transdisciplinarity. Accounting Organizations and Society, 36(3), 183-86.

Whittington, R., Basak-Yakis, B., \& Cailluet, L. (2011). Opening strategy: Evolution of a precarious profession. British Journal of Management, 22(3), 531-44.

Whittington, R., \& Cailluet, L. (2008). The crafts of strategy: Introduction to special issue. Long Range Planning, 41(3), 241-247.

Whittington, R., Jarzabkowski, P., Mayer, M., Mounoud, E., Nahapiet, J., \& Rouleau, L.(2003). Taking strategy seriously: Responsibility and reform for an important social practice. Journal of Management Inquiry, 12(4), 396-409.

Whittington, R., Molloy, E., Mayer, M., \& Smith, A. (2006). Practices of strategizing/ organizing, broadening strategy work and skills. Long Range Planning, 39(6), 615 - 629.

Whittle, A., \& Mueller, F. (2010). Strategy, enrolment and accounting: The politics of strategic ideas. 
Accounting, Auditing \& Accountability Journal, 23(5), 626-646.

Wittgenstein, L. (1951). Philosophical investigations. Oxford: Basil Blackwell.

Wooten, M.E., \& Hoffman, A. (2008). Organizational fields: Past, present and future of a core construct. In R. Greenwood, C. Oliver, R. Suddaby, \& K. Sahlin (Eds.), Sage handbook of organizational institutionalism (pp. 130-148). London: Sage Publications.

Zietsma, C., \& Lawrence, T.B. (2010). Institutional work in the transformation of an organizational field: The Interplay of boundary work and practice work. Administrative Science Quarterly, 55, 189221. 
Table 1 Examples Studies of Practices: Enabling and Constraining Effects ${ }^{1}$

\begin{tabular}{|c|c|c|c|c|c|}
\hline & $\begin{array}{l}\text { Theoretical } \\
\text { Base }\end{array}$ & $\begin{array}{l}\text { Main } \\
\text { Methodology }\end{array}$ & Context & Empirical focus & Findings about practices \\
\hline $\begin{array}{l}\text { Jarzabkowsk } \\
\text { i } 2003\end{array}$ & $\begin{array}{l}\text { Vygotsky: } \\
\text { activity theory }\end{array}$ & $\begin{array}{l}\text { Observation, } \\
\text { shadowing and } \\
\text { interviews in } \\
\text { three } \\
\text { organizations }\end{array}$ & $\begin{array}{l}\text { Not-for- } \\
\text { profit } \\
\text { (univers } \\
\text { ities) }\end{array}$ & Formal strategic practices & $\begin{array}{l}\text { Formal strategic practices can promote change if } \\
\text { they mediate contradictions between } \\
\text { constituents. }\end{array}$ \\
\hline $\begin{array}{l}\text { Vaara et al. } \\
2004\end{array}$ & $\begin{array}{l}\text { Critical } \\
\text { discourse } \\
\text { theory }\end{array}$ & $\begin{array}{l}\text { Discourse } \\
\text { analysis of cross- } \\
\text { industry } \\
\text { interviews and } \\
\text { published texts }\end{array}$ & $\begin{array}{l}\text { Profit } \\
\text { (airlines } \\
\text { ) }\end{array}$ & $\begin{array}{l}\text { Discursive practices of } \\
\text { strategy legitimation }\end{array}$ & $\begin{array}{l}\text { Strategies are constructed through discursive } \\
\text { practices that delegitimate (e.g. } \\
\text { problematization) or legitimate (e.g. } \\
\text { naturalization). }\end{array}$ \\
\hline $\begin{array}{l}\text { Molloy and } \\
\text { Whittington } \\
2005\end{array}$ & $\begin{array}{l}\text { General } \\
\text { practice theory }\end{array}$ & $\begin{array}{l}\text { Interviews and } \\
\text { photographs in } \\
\text { eight } \\
\text { organizations }\end{array}$ & $\begin{array}{l}\text { Mixed } \\
\text { (various } \\
\text { sectors) }\end{array}$ & Strategic change practices & $\begin{array}{l}\text { Material and analytical practices require a } \\
\text { skillful balance between standardisation and } \\
\text { customisation for effectiveness. }\end{array}$ \\
\hline $\begin{array}{l}\text { Jarzabkowsk } \\
\text { i and Fenton } \\
2006\end{array}$ & $\begin{array}{l}\text { General } \\
\text { practice theory }\end{array}$ & $\begin{array}{l}\text { Interviews in } \\
\text { three } \\
\text { organizations }\end{array}$ & $\begin{array}{l}\text { Mixed } \\
\text { (various } \\
\text { sectors) }\end{array}$ & $\begin{array}{l}\text { Strategizing and organizing } \\
\text { practices }\end{array}$ & $\begin{array}{l}\text { Pluralistic environments require dialogic } \\
\text { strategic planning practices, as small issues are } \\
\text { prone to rapid escalation. }\end{array}$ \\
\hline $\begin{array}{l}\text { Whittington, } \\
\text { Molloy, } \\
\text { Mayer, and } \\
\text { Smith (2006) }\end{array}$ & $\begin{array}{l}\text { General } \\
\text { practice theory }\end{array}$ & $\begin{array}{l}\text { Interviews and } \\
\text { observation in } \\
\text { eight } \\
\text { organizations } \\
\end{array}$ & $\begin{array}{l}\text { Mixed } \\
\text { (various } \\
\text { sectors) }\end{array}$ & $\begin{array}{l}\text { Strategy workshops, } \\
\text { projects and artifacts }\end{array}$ & $\begin{array}{l}\text { Strategic change involves practical and material } \\
\text { activities, where craft skill matters as much as } \\
\text { analysis. }\end{array}$ \\
\hline $\begin{array}{l}\text { Ezzamel and } \\
\text { Willmott }\end{array}$ & $\begin{array}{l}\text { Foucauldian } \\
\text { discourse }\end{array}$ & $\begin{array}{l}\text { Longitudinal } \\
\text { interviews in an }\end{array}$ & $\begin{array}{l}\text { Profit } \\
\text { (retail) }\end{array}$ & $\begin{array}{l}\text { Accounting practices in } \\
\text { strategy }\end{array}$ & $\begin{array}{l}\text { Accounting practices can become discursively } \\
\text { imbued with strategic significance with major }\end{array}$ \\
\hline
\end{tabular}

${ }^{1}$ Note that the studies in Tables1, 2 and 3 are categorized according to their primary empirical focus. However, many deal with more than one topic and are therefore relevant to other tables, too. 


\begin{tabular}{|c|c|c|c|c|c|}
\hline 2008 & analysis & organization & & & implications for the organization. \\
\hline $\begin{array}{l}\text { Giraudeau } \\
2008\end{array}$ & $\begin{array}{l}\text { Latour: Actor } \\
\text { Network } \\
\text { Theory }\end{array}$ & $\begin{array}{l}\text { Interviews and } \\
\text { archives in one } \\
\text { organization }\end{array}$ & $\begin{array}{l}\text { Profit } \\
\text { (automo } \\
\text { bile) }\end{array}$ & $\begin{array}{l}\text { Strategic planning } \\
\text { documents }\end{array}$ & $\begin{array}{l}\text { Drafts of strategic plans can promote } \\
\text { experimentation and openness in strategy work. }\end{array}$ \\
\hline $\begin{array}{l}\text { Heracleous } \\
\text { and Jacobs } \\
2008\end{array}$ & $\begin{array}{l}\text { Johnson: } \\
\text { embodied } \\
\text { cognition } \\
\text { theory }\end{array}$ & $\begin{array}{l}\text { Action research in } \\
\text { one organization }\end{array}$ & $\begin{array}{l}\text { Profit } \\
\text { (telecom } \\
\text { ) }\end{array}$ & $\begin{array}{l}\text { Embodied metaphors in } \\
\text { strategizing }\end{array}$ & $\begin{array}{l}\text { Embodied metaphors (i.e. physical artefacts) can } \\
\text { foster creative thinking }\end{array}$ \\
\hline $\begin{array}{l}\text { Jarzabkowsk } \\
\text { i and Seidl } \\
2008\end{array}$ & $\begin{array}{l}\text { Luhmann: } \\
\text { theory of } \\
\text { episodes }\end{array}$ & $\begin{array}{l}\text { Observation, } \\
\text { shadowing, } \\
\text { interviews and } \\
\text { documents in } \\
\text { three } \\
\text { organizations }\end{array}$ & $\begin{array}{l}\text { Not-for- } \\
\text { profit } \\
\text { (univers } \\
\text { ities) }\end{array}$ & Strategy meeting practices & $\begin{array}{l}\text { Strategy meeting practices (e.g. bracketing of } \\
\text { issues, turn-taking, voting and stage-managing) } \\
\text { stabilize or destabilize strategies. }\end{array}$ \\
\hline $\begin{array}{l}\text { Ocasio and } \\
\text { Joseph } 2008\end{array}$ & $\begin{array}{l}\text { Carnegie } \\
\text { School } \\
\text { tradition }\end{array}$ & $\begin{array}{l}\text { Historical } \\
\text { documents in one } \\
\text { organization }\end{array}$ & $\begin{array}{l}\text { Profit } \\
\text { (conglo } \\
\text { merate) }\end{array}$ & $\begin{array}{l}\text { Strategic planning over } \\
\text { time }\end{array}$ & $\begin{array}{l}\text { General Electric did not, as often claimed, lead } \\
\text { in abandoning strategic planning, but continually } \\
\text { renews its practices. }\end{array}$ \\
\hline $\begin{array}{l}\text { Eppler and } \\
\text { Platts } 2009\end{array}$ & $\begin{array}{l}\text { Visual } \\
\text { cognition } \\
\text { theory }\end{array}$ & $\begin{array}{l}\text { Action research in } \\
\text { five organizations }\end{array}$ & $\begin{array}{l}\text { Profit } \\
\text { (various } \\
\text { sectors) }\end{array}$ & $\begin{array}{l}\text { Interactive visual methods } \\
\text { in strategic planning }\end{array}$ & $\begin{array}{l}\text { Managers rely heavily on visual representations } \\
\text { for understanding and generating strategy. }\end{array}$ \\
\hline $\begin{array}{l}\text { Moisander } \\
\text { and Stenfors } \\
2009\end{array}$ & $\begin{array}{l}\text { Sociology of } \\
\text { technology }\end{array}$ & $\begin{array}{l}\text { Interviews, focus } \\
\text { groups and } \\
\text { documentary } \\
\text { analysis in one } \\
\text { organization }\end{array}$ & $\begin{array}{l}\text { Profit } \\
\text { (utilities } \\
\text { ) }\end{array}$ & $\begin{array}{l}\text { Strategy tools, their } \\
\text { development, and use }\end{array}$ & $\begin{array}{l}\text { Strategy tool designers may misunderstand the } \\
\text { epistemic culture of tool users, exaggerating } \\
\text { problem solving and rationality. }\end{array}$ \\
\hline $\begin{array}{l}\text { Jarratt and } \\
\text { Stiles } 2010\end{array}$ & $\begin{array}{l}\text { Vygotsky: } \\
\text { activity theory }\end{array}$ & $\begin{array}{l}\text { Cross- } \\
\text { organizational } \\
\text { interviews with } \\
\text { senior managers }\end{array}$ & $\begin{array}{l}\text { Profit } \\
\text { (various } \\
\text { sectors) }\end{array}$ & $\begin{array}{l}\text { Strategy methods and tools } \\
\text { (e.g. SWOT) }\end{array}$ & $\begin{array}{l}\text { Analysis tools such as SWOT may be used in a } \\
\text { routinized, reflective or engaged manner. }\end{array}$ \\
\hline $\begin{array}{l}\text { Cabantous et } \\
\text { al. } 2010\end{array}$ & $\begin{array}{l}\text { Callon and } \\
\text { Latour: } \\
\text { performativity }\end{array}$ & $\begin{array}{l}\text { Cross- } \\
\text { organizational } \\
\text { documentary } \\
\text { analysis and } \\
\end{array}$ & Mixed & $\begin{array}{l}\text { The field of decision } \\
\text { analysis and its techniques }\end{array}$ & $\begin{array}{l}\text { Rational decision-making techniques involve the } \\
\text { construction of social-material assemblages. }\end{array}$ \\
\hline
\end{tabular}




\begin{tabular}{|c|c|c|c|c|c|}
\hline & & interviews & & & \\
\hline $\begin{array}{l}\text { Hendry et al. } \\
2010\end{array}$ & $\begin{array}{l}\text { General } \\
\text { practice theory }\end{array}$ & $\begin{array}{l}\text { Interviews with } \\
\text { senior managers } \\
\text { in } 21 \\
\text { organizations }\end{array}$ & $\begin{array}{l}\text { Mixed } \\
\text { (various } \\
\text { sectors) }\end{array}$ & $\begin{array}{l}\text { Board-level strategizing } \\
\text { practices }\end{array}$ & $\begin{array}{l}\text { Combinations of procedural and interactive } \\
\text { practices can lead to minimalist, } \\
\text { transformational, continuous or oversight } \\
\text { involvement by boards. }\end{array}$ \\
\hline $\begin{array}{l}\text { Johnson et } \\
\text { al. } 2010\end{array}$ & $\begin{array}{l}\text { Anthropologic } \\
\text { al ritual theory }\end{array}$ & $\begin{array}{l}\text { Group interviews } \\
\text { in one } \\
\text { organization and } \\
\text { observation in } \\
\text { three others }\end{array}$ & $\begin{array}{l}\text { Mixed } \\
\text { (various } \\
\text { sectors) }\end{array}$ & $\begin{array}{l}\text { Strategy workshops and } \\
\text { their ritualization }\end{array}$ & $\begin{array}{l}\text { Ritualization (e.g. degree of removal, use of } \\
\text { liturgy, role of specialists) influences the } \\
\text { outcomes of strategy workshops. }\end{array}$ \\
\hline $\begin{array}{l}\text { Jørgensen } \\
\text { and Messner } \\
2010\end{array}$ & $\begin{array}{l}\text { Schatzki: } \\
\text { practice theory }\end{array}$ & $\begin{array}{l}\text { Participant } \\
\text { observation, } \\
\text { interviews and } \\
\text { archives in one } \\
\text { organization }\end{array}$ & $\begin{array}{l}\text { Profit } \\
\text { (wine) }\end{array}$ & $\begin{array}{l}\text { Accounting information in } \\
\text { new product strategy }\end{array}$ & $\begin{array}{l}\text { New strategy is developed through the flexible } \\
\text { interpretation of incommensurate evaluation } \\
\text { practices (accounting etc.). }\end{array}$ \\
\hline $\begin{array}{l}\text { Vaara et al. } \\
2010\end{array}$ & $\begin{array}{l}\text { Critical } \\
\text { discourse } \\
\text { analysis }\end{array}$ & $\begin{array}{l}\text { Strategic plan } \\
\text { texts and } \\
\text { interviews in one } \\
\text { organization }\end{array}$ & $\begin{array}{l}\text { Not-for- } \\
\text { profit } \\
\text { (city) }\end{array}$ & $\begin{array}{l}\text { Discursive practices in } \\
\text { strategic plans }\end{array}$ & $\begin{array}{l}\text { Strategic plans have important power effects } \\
\text { based on discursive practices such as self- } \\
\text { authorization, forced consensus and discursive } \\
\text { innovation }\end{array}$ \\
\hline $\begin{array}{l}\text { Whittle and } \\
\text { Mueller } \\
2010\end{array}$ & $\begin{array}{l}\text { Latour: Actor } \\
\text { Network } \\
\text { Theory }\end{array}$ & $\begin{array}{l}\text { Observation and } \\
\text { interviews in one } \\
\text { organization }\end{array}$ & $\begin{array}{l}\text { Profit } \\
\text { (telecom } \\
\text { ) }\end{array}$ & $\begin{array}{l}\text { Management accounting } \\
\text { systems in strategy }\end{array}$ & $\begin{array}{l}\text { The accounting system is central to political } \\
\text { struggles over the strategic agenda. }\end{array}$ \\
\hline $\begin{array}{l}\text { Gomez and } \\
\text { Bouty } 2011\end{array}$ & $\begin{array}{l}\text { Bourdieu: } \\
\text { field, habitus } \\
\text { and capital }\end{array}$ & $\begin{array}{l}\text { Observation, } \\
\text { interviews and } \\
\text { statistics in one } \\
\text { organization. }\end{array}$ & $\begin{array}{l}\text { Profit } \\
\text { (gastron } \\
\text { omy) }\end{array}$ & $\begin{array}{l}\text { Emergence of new } \\
\text { strategies }\end{array}$ & $\begin{array}{l}\text { Agents create new practices by linking the micro } \\
\text { (habitus and capital) and the macro (field) } \\
\text { through implicit action. }\end{array}$ \\
\hline Kaplan 2011 & $\begin{array}{l}\text { General } \\
\text { practice } \\
\text { theory: } \\
\text { discourse }\end{array}$ & $\begin{array}{l}\text { Ethnography } \\
\text { focused on } \\
\text { projects in one } \\
\text { organization }\end{array}$ & $\begin{array}{l}\text { Profit } \\
\text { (telecom } \\
\text { ) }\end{array}$ & $\begin{array}{l}\text { PowerPoint as discursive } \\
\text { practice }\end{array}$ & $\begin{array}{l}\text { PowerPoints are part of the 'epistemic } \\
\text { machinery' of strategy. }\end{array}$ \\
\hline $\begin{array}{l}\text { O’Brien } \\
2011\end{array}$ & Not applicable & $\begin{array}{l}\text { Large-scale } \\
\text { survey of } \\
\text { practitioners }\end{array}$ & Mixed & $\begin{array}{l}\text { Use of operational research } \\
\text { and strategy tools }\end{array}$ & $\begin{array}{l}\text { OR specialists often support strategy processes } \\
\text { with analytical tools, but rarely with 'soft' OR } \\
\text { tools. }\end{array}$ \\
\hline Kornberger & Foucauldian & Textual analysis, & Not-for- & The power effects of & Strategy as text is 'performative' in redefining \\
\hline
\end{tabular}




\begin{tabular}{|l|l|l|l|l|l|}
\hline $\begin{array}{l}\text { and Clegg } \\
2011\end{array}$ & $\begin{array}{l}\text { discourse } \\
\text { analysis }\end{array}$ & $\begin{array}{l}\text { interviews and } \\
\text { observation in one } \\
\text { organization }\end{array}$ & $\begin{array}{l}\text { profit } \\
\text { (city) }\end{array}$ & strategic plans & and disciplining the organization. \\
\hline
\end{tabular}


Table 2 Examples of Studies of Praxis: What Goes on in Episodes of Strategy-Making

\begin{tabular}{|c|c|c|c|c|c|}
\hline & $\begin{array}{l}\text { Theoretical } \\
\text { base }\end{array}$ & Main methodology & Context & Empirical focus & Findings about praxis \\
\hline $\begin{array}{l}\text { Maitlis and } \\
\text { Lawrence } \\
2003\end{array}$ & $\begin{array}{l}\text { Discourse and } \\
\text { political } \\
\text { theories }\end{array}$ & $\begin{array}{l}\text { Observation, } \\
\text { interviews and } \\
\text { documentary analysis } \\
\text { in one organization }\end{array}$ & $\begin{array}{l}\text { Not-for-profit } \\
\text { (orchestra) }\end{array}$ & Failure in strategizing & $\begin{array}{l}\text { Lack of shared discourse, and a focus on } \\
\text { weaknesses rather than strengths, can lead } \\
\text { to strategizing failure. }\end{array}$ \\
\hline Regnér 2003 & $\begin{array}{l}\text { General } \\
\text { practice theory }\end{array}$ & $\begin{array}{l}\text { Observation, } \\
\text { interviews and } \\
\text { documents in four } \\
\text { organizations }\end{array}$ & $\begin{array}{l}\text { Profit (various } \\
\text { sectors) }\end{array}$ & $\begin{array}{l}\text { Strategy development } \\
\text { in the center and } \\
\text { periphery. }\end{array}$ & $\begin{array}{l}\text { Strategies emerge more inductively from } \\
\text { the organizational periphery, more } \\
\text { deductively from the corporate centre. }\end{array}$ \\
\hline Salvato 2003 & $\begin{array}{l}\text { Dynamic } \\
\text { capabilities } \\
\text { theory }\end{array}$ & $\begin{array}{l}\text { Interviews and some } \\
\text { observation in two } \\
\text { organizations }\end{array}$ & $\begin{array}{l}\text { Profit } \\
\text { (design and } \\
\text { mail order) }\end{array}$ & $\begin{array}{l}\text { The recombination of } \\
\text { micro-strategies. }\end{array}$ & $\begin{array}{l}\text { Dynamic capabilities build on the } \\
\text { repeated recombination of stable micro } \\
\text { processes, rather than disruptive change. }\end{array}$ \\
\hline $\begin{array}{l}\text { Samra- } \\
\text { Fredricks } \\
2003\end{array}$ & $\begin{array}{l}\text { Garfinkel: } \\
\text { ethnomethodol } \\
\text { ogy }\end{array}$ & $\begin{array}{l}\text { Ethnographic } \\
\text { observation and audio } \\
\text { recording in one } \\
\text { organization }\end{array}$ & $\begin{array}{l}\text { Profit } \\
\text { (Manufacturin } \\
\text { g) }\end{array}$ & $\begin{array}{l}\text { Change recipient } \\
\text { sensemaking }\end{array}$ & $\begin{array}{l}\text { Strategizing involves use of rhetorical } \\
\text { tactics such as emotion, organizational } \\
\text { history, apt metaphor, and the local } \\
\text { "moral order". }\end{array}$ \\
\hline $\begin{array}{l}\text { Balogun and } \\
\text { Johnson } \\
2005\end{array}$ & $\begin{array}{l}\text { Weickian } \\
\text { sensemaking }\end{array}$ & $\begin{array}{l}\text { Managers' diaries, } \\
\text { interviews, focus } \\
\text { groups and feedback } \\
\text { meetings in one } \\
\text { organization }\end{array}$ & $\begin{array}{l}\text { Profit } \\
\text { (utilities) }\end{array}$ & $\begin{array}{l}\text { Change recipient } \\
\text { sensemaking }\end{array}$ & $\begin{array}{l}\text { Lateral interactions amongst middle } \\
\text { managers are crucial in the } \\
\text { implementation of strategic change. }\end{array}$ \\
\hline $\begin{array}{l}\text { Stensaker } \\
\text { and } \\
\text { Falkenberg } \\
2007\end{array}$ & $\begin{array}{l}\text { Weickian: } \\
\text { sensemaking }\end{array}$ & $\begin{array}{l}\text { Observation and } \\
\text { interviews in three } \\
\text { units in one } \\
\text { organization }\end{array}$ & Profit (oil) & $\begin{array}{l}\text { Responses to strategic } \\
\text { change processes. }\end{array}$ & $\begin{array}{l}\text { Individuals’ interpretations of corporate } \\
\text { change shape both units’ responses and } \\
\text { organization-level interpretations. }\end{array}$ \\
\hline $\begin{array}{l}\text { Ambrosini et } \\
\text { al, } 2007\end{array}$ & $\begin{array}{l}\text { Resource- } \\
\text { based view }\end{array}$ & $\begin{array}{l}\text { Observation and } \\
\text { interviews in two } \\
\text { divisions }\end{array}$ & $\begin{array}{l}\text { Profit } \\
\text { (financial } \\
\text { services) }\end{array}$ & $\begin{array}{l}\text { Managers' and } \\
\text { employees’ work and } \\
\text { coordinating activities }\end{array}$ & $\begin{array}{l}\text { Managers' reinforcing activities, informal } \\
\text { interactions and physical layouts are } \\
\text { crucial to competitive advantage. }\end{array}$ \\
\hline $\begin{array}{l}\text { Jarzabkowski } \\
2008\end{array}$ & $\begin{array}{l}\text { Giddens: } \\
\text { structuration } \\
\text { theory }\end{array}$ & $\begin{array}{l}\text { Observation, } \\
\text { shadowing and } \\
\text { interviews in three }\end{array}$ & $\begin{array}{l}\text { Not-for-profit } \\
\text { (universities) }\end{array}$ & $\begin{array}{l}\text { The shaping of } \\
\text { strategy as a sequential } \\
\text { process }\end{array}$ & $\begin{array}{l}\text { Strongly institutionalized contexts require } \\
\text { shaping of strategy simultaneously in the } \\
\text { action and the institutional realms. }\end{array}$ \\
\hline
\end{tabular}




\begin{tabular}{|c|c|c|c|c|c|}
\hline & & organizations & & & \\
\hline Kaplan 2008 & $\begin{array}{l}\text { Social } \\
\text { movement } \\
\text { theory }\end{array}$ & $\begin{array}{l}\text { Ethnography focused } \\
\text { on projects in one } \\
\text { organization }\end{array}$ & $\begin{array}{l}\text { Profit } \\
\text { (technology) }\end{array}$ & $\begin{array}{l}\text { Strategizing as } \\
\text { framing and politics. }\end{array}$ & $\begin{array}{l}\text { Actors engage in highly political framing } \\
\text { practices to make their frames resonate } \\
\text { and to gain support. }\end{array}$ \\
\hline $\begin{array}{l}\text { Jarzabkowski } \\
\text { and Balogun } \\
2009\end{array}$ & $\begin{array}{l}\text { Vygotsky: } \\
\text { activity theory }\end{array}$ & $\begin{array}{l}\text { Interviews in one } \\
\text { organization }\end{array}$ & $\begin{array}{l}\text { Profit } \\
\text { (consumer } \\
\text { goods) }\end{array}$ & $\begin{array}{l}\text { Strategic planning and } \\
\text { integration }\end{array}$ & $\begin{array}{l}\text { Given varying interests, integration arises } \\
\text { from active negotiations and compromises } \\
\text { between the actors in strategic planning. }\end{array}$ \\
\hline $\begin{array}{l}\text { Balogun et } \\
\text { al. } 2011\end{array}$ & $\begin{array}{l}\text { Critical } \\
\text { discourse } \\
\text { analysis }\end{array}$ & $\begin{array}{l}\text { Interviews in one } \\
\text { organization }\end{array}$ & $\begin{array}{l}\text { Profit } \\
\text { (consumer } \\
\text { goods) }\end{array}$ & $\begin{array}{l}\text { The evolution of } \\
\text { subsidiary roles }\end{array}$ & $\begin{array}{l}\text { Changes in strategic planning may evoke } \\
\text { selling, resistance and reconciliation } \\
\text { discourses in HQs and subsidiary. }\end{array}$ \\
\hline $\begin{array}{l}\text { Denis et al. } \\
2011\end{array}$ & $\begin{array}{l}\text { Latour: Actor } \\
\text { Network } \\
\text { Theory }\end{array}$ & $\begin{array}{l}\text { Observation, internal } \\
\text { and external } \\
\text { documents and } \\
\text { interviews in three } \\
\text { merging }\end{array}$ & $\begin{array}{l}\text { Not-for-profit } \\
\text { (hospitals) }\end{array}$ & Failure of strategizing & $\begin{array}{l}\text { Strategizing can lead to ‘escalating } \\
\text { indecision’ where divergent conceptions } \\
\text { prevent a project from materializing in a } \\
\text { tangible form. }\end{array}$ \\
\hline $\begin{array}{l}\text { Sillence et al. } \\
2011\end{array}$ & $\begin{array}{l}\text { Rhetorical } \\
\text { theory }\end{array}$ & $\begin{array}{l}\text { Observation and } \\
\text { interviews in one } \\
\text { organization }\end{array}$ & $\begin{array}{l}\text { Not-for-profit } \\
\text { (business } \\
\text { school) }\end{array}$ & $\begin{array}{l}\text { Shaping strategy } \\
\text { through rhetoric }\end{array}$ & $\begin{array}{l}\text { Rhetorical constructions of ambiguity } \\
\text { (protective, invitation and adaptive) } \\
\text { follow a processual pattern that shapes } \\
\text { emergent strategic action. }\end{array}$ \\
\hline $\begin{array}{l}\text { Clarke et al } \\
2011\end{array}$ & $\begin{array}{l}\text { Discourse } \\
\text { theory }\end{array}$ & $\begin{array}{l}\text { Ethnographic } \\
\text { observation of a } \\
\text { conversation in one } \\
\text { organization }\end{array}$ & $\begin{array}{l}\text { Profit } \\
\text { (manufacturin } \\
\text { g) }\end{array}$ & $\begin{array}{l}\text { Top managers' } \\
\text { discourse. }\end{array}$ & $\begin{array}{l}\text { Contextual knowledge of incentives, } \\
\text { locale and institutional setting transforms } \\
\text { the meaning of a strategic conversation. }\end{array}$ \\
\hline $\begin{array}{l}\text { Fauré and } \\
\text { Rouleau, } \\
2011\end{array}$ & $\begin{array}{l}\text { General } \\
\text { practice theory }\end{array}$ & $\begin{array}{l}\text { Observation and } \\
\text { interviews in one } \\
\text { organization }\end{array}$ & $\begin{array}{l}\text { Profit } \\
\text { (construction) }\end{array}$ & $\begin{array}{l}\text { Strategy and budget } \\
\text { making. }\end{array}$ & $\begin{array}{l}\text { Strategy implementation requires the } \\
\text { artful reinterpretation of financial } \\
\text { numbers by middle managers. }\end{array}$ \\
\hline $\begin{array}{l}\text { Spee and } \\
\text { Jarzabkowski } \\
2011\end{array}$ & $\begin{array}{l}\text { Ricoeur and } \\
\text { Montreal } \\
\text { School } \\
\text { communicatio } \\
\mathrm{n}\end{array}$ & $\begin{array}{l}\text { Observation and } \\
\text { interviews in one } \\
\text { organization }\end{array}$ & $\begin{array}{l}\text { Not-for-profit } \\
\text { (university) }\end{array}$ & $\begin{array}{l}\text { Strategic planning as a } \\
\text { communicative } \\
\text { process }\end{array}$ & $\begin{array}{l}\text { The recursive interplay between planning } \\
\text { text and talk enables agreement and the } \\
\text { minimization of competing } \\
\text { interpretations. }\end{array}$ \\
\hline
\end{tabular}




\begin{tabular}{|l|l|l|l|l|l|}
\hline $\begin{array}{l}\text { Aggerholm } \\
\text { et al. } \\
\text { (forthcoming } \\
\text { ) }\end{array}$ & $\begin{array}{l}\text { Communicatio } \\
\text { n theory }\end{array}$ & $\begin{array}{l}\text { Video and audio } \\
\text { recordings, documents } \\
\text { in one organization }\end{array}$ & $\begin{array}{l}\text { Profit } \\
\text { (manufacturin } \\
\text { g) }\end{array}$ & $\begin{array}{l}\text { Series of strategy } \\
\text { conversations. }\end{array}$ & $\begin{array}{l}\text { Strategy texts and talk are liable to be } \\
\text { interpreted in multiple ways over time, } \\
\text { thus leading to ambiguity. }\end{array}$ \\
\hline $\begin{array}{l}\text { Liu and } \\
\text { Maitlis } \\
\text { (forthcoming } \\
\text { ) }\end{array}$ & $\begin{array}{l}\text { Weick: } \\
\text { sensemaking }\end{array}$ & $\begin{array}{l}\text { Video and audio } \\
\text { recordings in one } \\
\text { organization }\end{array}$ & $\begin{array}{l}\text { Profit (games } \\
\text { industry) }\end{array}$ & $\begin{array}{l}\text { Emotion in strategy } \\
\text { conversations }\end{array}$ & $\begin{array}{l}\text { Different types of strategizing process are } \\
\text { associated with different kinds of } \\
\text { emotional dynamics }\end{array}$ \\
\hline
\end{tabular}


Table 3 Examples Studies of Practitioners: Roles and Identities of Actors

\begin{tabular}{|c|c|c|c|c|c|}
\hline & $\begin{array}{l}\text { Theoretical } \\
\text { Base }\end{array}$ & Main methodology & Context & Empirical focus & Findings about practitioners \\
\hline $\begin{array}{l}\text { Mantere } \\
2005\end{array}$ & $\begin{array}{l}\text { Giddens: } \\
\text { structuration } \\
\text { theory }\end{array}$ & $\begin{array}{l}\text { Interviews with } \\
\text { middle-managers and } \\
\text { lower-levels in twelve } \\
\text { organizations } \\
\end{array}$ & $\begin{array}{l}\text { Mixed } \\
\text { (various } \\
\text { sectors) }\end{array}$ & $\begin{array}{l}\text { Strategy 'champions' and } \\
\text { participation }\end{array}$ & $\begin{array}{l}\text { Flexible strategy practices allow } \\
\text { creativity but structured strategy } \\
\text { practices afford security for wider } \\
\text { participation }\end{array}$ \\
\hline $\begin{array}{l}\text { Rouleau } \\
2005\end{array}$ & $\begin{array}{l}\text { Weick: } \\
\text { sensemaking }\end{array}$ & $\begin{array}{l}\text { Participant } \\
\text { observation, } \\
\text { interviews and } \\
\text { documentary analysis } \\
\text { in one organization }\end{array}$ & $\begin{array}{l}\text { Profit } \\
\text { (clothing) }\end{array}$ & $\begin{array}{l}\text { Middle managers in strategic } \\
\text { change }\end{array}$ & $\begin{array}{l}\text { Middle managers make use of four } \\
\text { micro-practices to interpret and sell } \\
\text { strategic change to stakeholders . }\end{array}$ \\
\hline $\begin{array}{l}\text { Samra- } \\
\text { Fredericks } \\
2005\end{array}$ & $\begin{array}{l}\text { Critical } \\
\text { analysis } \\
\text { (Habermas and } \\
\text { ethnomethodol } \\
\text { ogy) }\end{array}$ & $\begin{array}{l}\text { Ethnography in one } \\
\text { organization }\end{array}$ & $\begin{array}{l}\text { Profit } \\
\text { (manufact } \\
\text { uring) }\end{array}$ & Power in strategizing & $\begin{array}{l}\text { Strategy discourse reproduces subject } \\
\text { positions for managers (including } \\
\text { heroism and masculine values) }\end{array}$ \\
\hline $\begin{array}{l}\text { Laine and } \\
\text { Vaara } 2007\end{array}$ & $\begin{array}{l}\text { Critical } \\
\text { discourse } \\
\text { analysis }\end{array}$ & $\begin{array}{l}\text { Participant observation } \\
\text { and interviews in one } \\
\text { organization }\end{array}$ & $\begin{array}{l}\text { Profit } \\
\text { (Engineer } \\
\text { ing) }\end{array}$ & $\begin{array}{l}\text { The discursive construction of } \\
\text { subjectivity }\end{array}$ & $\begin{array}{l}\text { Strategy discourse is central to } \\
\text { struggles over control and resistance } \\
\text { between top management, middle } \\
\text { managers and other organizational } \\
\text { members. }\end{array}$ \\
\hline $\begin{array}{l}\text { Paroutis and } \\
\text { Pettigrew } \\
2007\end{array}$ & $\begin{array}{l}\text { General } \\
\text { practice theory }\end{array}$ & $\begin{array}{l}\text { Interviews in two } \\
\text { divisions and centre } \\
\text { one organization }\end{array}$ & $\begin{array}{l}\text { Profit } \\
\text { (utilities) }\end{array}$ & $\begin{array}{l}\text { Strategy teams across } \\
\text { organizational levels }\end{array}$ & $\begin{array}{l}\text { Strategy work is carried out in } \\
\text { distributed teams at different } \\
\text { organizational levels, which requires } \\
\text { interaction and coordination. }\end{array}$ \\
\hline $\begin{array}{l}\text { Mantere } \\
2008\end{array}$ & $\begin{array}{l}\text { Giddens: } \\
\text { structuration }\end{array}$ & $\begin{array}{l}\text { Interviews and other } \\
\text { data in twelve }\end{array}$ & $\begin{array}{l}\text { Mixed } \\
\text { (various }\end{array}$ & Middle managers as strategists & $\begin{array}{l}\text { Middle manager involvement in } \\
\text { strategy relies on top-level granting of }\end{array}$ \\
\hline
\end{tabular}




\begin{tabular}{|c|c|c|c|c|c|}
\hline & theory & organizations & sectors) & & $\begin{array}{l}\text { legitimacy, resources, trust and } \\
\text { judgement. }\end{array}$ \\
\hline $\begin{array}{l}\text { Mantere and } \\
\text { Vaara } 2008\end{array}$ & $\begin{array}{l}\text { Discourse } \\
\text { theory }\end{array}$ & $\begin{array}{l}\text { Interviews and other } \\
\text { data in twelve } \\
\text { organizations }\end{array}$ & $\begin{array}{l}\text { Mixed } \\
\text { (various } \\
\text { sectors) }\end{array}$ & $\begin{array}{l}\text { Discursive practices and strategy } \\
\text { participation }\end{array}$ & $\begin{array}{l}\text { 'Mystifying', 'disciplining and } \\
\text { ‘technologizing’ discourses inhibit } \\
\text { participation; ‘self-actualization', } \\
\text { 'dialogization' and ‘concretizing' } \\
\text { discourses facilitate it. }\end{array}$ \\
\hline $\begin{array}{l}\text { Nordqvist } \\
\text { and Melin } \\
2008\end{array}$ & $\begin{array}{l}\text { General } \\
\text { practice theory }\end{array}$ & $\begin{array}{l}\text { Observation, } \\
\text { interviews and } \\
\text { document analysis in } \\
\text { two organizations }\end{array}$ & $\begin{array}{l}\text { Profit } \\
\text { (various } \\
\text { sectors) }\end{array}$ & $\begin{array}{l}\text { Strategy consultants and } \\
\text { advocates }\end{array}$ & $\begin{array}{l}\text { Strategic planning champions may } \\
\text { perform the roles of social } \\
\text { craftsperson, artful interpreter or } \\
\text { known stranger. }\end{array}$ \\
\hline $\begin{array}{l}\text { Angwin et al. } \\
2009\end{array}$ & $\begin{array}{l}\text { General } \\
\text { practice theory }\end{array}$ & $\begin{array}{l}\text { Cross-organizational } \\
\text { interviews }\end{array}$ & $\begin{array}{l}\text { Profit } \\
\text { (various } \\
\text { sectors) }\end{array}$ & $\begin{array}{l}\text { The role of senior strategy } \\
\text { directors }\end{array}$ & $\begin{array}{l}\text { Senior strategy directors have an } \\
\text { 'interconnected' position in strategy } \\
\text { formation and implementation. }\end{array}$ \\
\hline $\begin{array}{l}\text { McCabe } \\
2010\end{array}$ & $\begin{array}{l}\text { Foucauldian } \\
\text { concept of } \\
\text { power }\end{array}$ & $\begin{array}{l}\text { Interviews and } \\
\text { documentary analysis } \\
\text { in one organization }\end{array}$ & $\begin{array}{l}\text { Profit } \\
\text { (building } \\
\text { society) }\end{array}$ & Power in strategizing & $\begin{array}{l}\text { Power is exercised in ambiguous and } \\
\text { contradictory ways, both supporting } \\
\text { managers' initiatives and creating } \\
\text { possibilities for resistance. }\end{array}$ \\
\hline $\begin{array}{l}\text { Suominen } \\
\text { and Mantere } \\
2010\end{array}$ & $\begin{array}{l}\text { De Certeau: } \\
\text { practice theory }\end{array}$ & $\begin{array}{l}\text { Interviews, } \\
\text { observations and } \\
\text { document analysis in } \\
\text { three organizations }\end{array}$ & Mixed & Middle managers in strategizing & $\begin{array}{l}\text { Middle managers creatively 'consume' } \\
\text { strategies, instrumentally as well as } \\
\text { playfully and intimately. }\end{array}$ \\
\hline $\begin{array}{l}\text { Nordquist, } \\
2011\end{array}$ & $\begin{array}{l}\text { Simmel and } \\
\text { Giddens }\end{array}$ & $\begin{array}{l}\text { Observation and } \\
\text { interviews in three } \\
\text { organizations }\end{array}$ & $\begin{array}{l}\text { Profit } \\
\text { (various } \\
\text { sectors) }\end{array}$ & $\begin{array}{l}\text { Strategy practitioners in family } \\
\text { businesses }\end{array}$ & $\begin{array}{l}\text { Strategy consultants play role of } \\
\text { 'Simmelian strangers', neither too } \\
\text { close nor too far to top internal } \\
\text { managers. }\end{array}$ \\
\hline $\begin{array}{l}\text { Rouleau and } \\
\text { Balogun } \\
2011\end{array}$ & $\begin{array}{l}\text { Weick: } \\
\text { sensemaking }\end{array}$ & $\begin{array}{l}\text { Interviews in two } \\
\text { organizations }\end{array}$ & Mixed & $\begin{array}{l}\text { Middle managers in strategic } \\
\text { change }\end{array}$ & $\begin{array}{l}\text { Discursive competence in strategy } \\
\text { involves performing the conversation } \\
\text { and the ability to set the socio-political } \\
\text { 'scene'. }\end{array}$ \\
\hline $\begin{array}{l}\text { Whittington } \\
\text { et al. } 2011\end{array}$ & $\begin{array}{l}\text { Abbott: } \\
\text { sociology of } \\
\text { the professions }\end{array}$ & $\begin{array}{l}\text { Cross-organizational } \\
\text { statistics and } \\
\text { documents }\end{array}$ & Mixed & $\begin{array}{l}\text { The historical development of } \\
\text { the strategy profession }\end{array}$ & $\begin{array}{l}\text { Strategic planners are an enduring but } \\
\text { structurally-precarious and opening } \\
\text { profession. }\end{array}$ \\
\hline
\end{tabular}


Table 4 Strategy-as-Practice and Related Traditions in Strategy and Institutional Research

\begin{tabular}{|l|l|l|l|l|l|}
\hline & $\begin{array}{l}\text { Strategy } \\
\text { Process }\end{array}$ & $\begin{array}{l}\text { Micro- } \\
\text { Foundations }\end{array}$ & $\begin{array}{l}\text { Macro- } \\
\text { Institutional } \\
\text { Theory }\end{array}$ & Institutional Work & Strategy as Practice \\
\hline $\begin{array}{l}\text { Empirical } \\
\text { focus } \\
\text { (macro / } \\
\text { micro) }\end{array}$ & $\begin{array}{l}\text { Focus on } \\
\text { individual, } \\
\text { organizational } \\
\text { and team level } \\
\text { phenomena }\end{array}$ & $\begin{array}{l}\text { Focus on micro- } \\
\text { level decision- } \\
\text { making and } \\
\text { strategies }\end{array}$ & $\begin{array}{l}\text { Focus on inter- } \\
\text { organizational } \\
\text { fields and } \\
\text { practices }\end{array}$ & $\begin{array}{l}\text { Focus on individuals' } \\
\text { activity in creating, } \\
\text { maintaining and } \\
\text { changing institutions }\end{array}$ & $\begin{array}{l}\text { Focus on } \\
\text { organizational and } \\
\text { institutional practices } \\
\text { that enable and } \\
\text { constrain action }\end{array}$ \\
\hline $\begin{array}{l}\text { Structure / } \\
\text { agency }\end{array}$ & $\begin{array}{l}\text { Emphasis on } \\
\text { managerial } \\
\text { agency }\end{array}$ & $\begin{array}{l}\text { Emphasis on } \\
\text { agency in terms of } \\
\text { individual } \\
\text { decisions and } \\
\text { actions }\end{array}$ & $\begin{array}{l}\text { Emphasis on } \\
\text { institutions as } \\
\text { powerful } \\
\text { structures }\end{array}$ & $\begin{array}{l}\text { Emphasis on creative } \\
\text { and transformative } \\
\text { capacity of individuals }\end{array}$ & $\begin{array}{l}\text { Emphasis on practices } \\
\text { as mediating between } \\
\text { structure and agency }\end{array}$ \\
\hline $\begin{array}{l}\text { Process / } \\
\text { outcome }\end{array}$ & $\begin{array}{l}\text { How } \\
\text { managerial } \\
\text { processes } \\
\text { contribute to } \\
\text { organizational } \\
\text { performance }\end{array}$ & $\begin{array}{l}\text { How behaviors } \\
\text { and decisions } \\
\text { impact } \\
\text { organizational } \\
\text { performance }\end{array}$ & $\begin{array}{l}\text { How institutions } \\
\text { develop and } \\
\text { structure behavior }\end{array}$ & $\begin{array}{l}\text { How institutional } \\
\text { continuity and change } \\
\text { rely on institutional } \\
\text { work }\end{array}$ & $\begin{array}{l}\text { How institutionalized } \\
\text { practices are both } \\
\text { shapers and outcomes } \\
\text { of activity }\end{array}$ \\
\hline
\end{tabular}

